Review

\title{
Finding Nano: Challenges Involved in Monitoring the Presence and Fate of Engineered Titanium Dioxide Nanoparticles in Aquatic Environments
}

\author{
Simone Heilgeist ${ }^{1,2, *(\mathbb{C}, \text { Ryo Sekine }}{ }^{3,4}$, Oz Sahin ${ }^{1,2,5}$ (i) and Rodney A. Stewart ${ }^{1,2}$ (1) \\ 1 School of Engineering and Built Environment, Gold Coast Campus, Griffith University, \\ Logan, QLD 4222, Australia; o.sahin@griffith.edu.au (O.S.); r.stewart@griffith.edu.au (R.A.S.) \\ 2 Cities Research Institute, Gold Coast Campus, Griffith University, Logan, QLD 4222, Australia \\ 3 School of Science and Engineering, University of Sunshine Coast, Moreton Bay, \\ Brisbane, QLD 4502, Australia; rsekine@usc.edu.au \\ 4 Environmental Futures Research Institute, Gold Coast Campus, Griffith University, \\ Logan, QLD 4222, Australia \\ 5 Climate Change Response Program, Gold Coast Campus, Griffith University, Logan, QLD 4222, Australia \\ * Correspondence: simone.heilgeist@griffithuni.edu.au
}

Citation: Heilgeist, S.; Sekine, R.; Sahin, O.; Stewart, R.A. Finding Nano: Challenges Involved in Monitoring the Presence and Fate of Engineered Titanium Dioxide Nanoparticles in Aquatic Environments. Water 2021, 13, 734. https://doi.org/10.3390/w13050734

Academic Editor: Miren López de Alda Villaizán

Received: 6 February 2021

Accepted: 5 March 2021

Published: 8 March 2021

Publisher's Note: MDPI stays neutral with regard to jurisdictional claims in published maps and institutional affiliations.

Copyright: (c) 2021 by the authors. Licensee MDPI, Basel, Switzerland. This article is an open access article distributed under the terms and conditions of the Creative Commons Attribution (CC BY) license (https:// creativecommons.org/licenses/by/ $4.0 /)$.

\begin{abstract}
In recent years, titanium dioxide $\left(\mathrm{TiO}_{2}\right)$ has increasingly been used as an inorganic ultraviolet (UV) filter for sun protection. However, nano- $\mathrm{TiO}_{2}$ may also pose risks to the health of humans and the environment. Thus, to adequately assess its potential adverse effects, a comprehensive understanding of the behaviour and fate of $\mathrm{TiO}_{2}$ in different environments is crucial. Advances in analytical and modelling methods continue to improve researchers' ability to quantify and determine the state of nano- $\mathrm{TiO}_{2}$ in various environments. However, due to the complexity of environmental and nanoparticle factors and their interplay, this remains a challenging and poorly resolved feat. This paper aims to provide a focused summary of key particle and environmental characteristics that influence the behaviour and fate of sunscreen-derived $\mathrm{TiO}_{2}$ in swimming pool water and natural aquatic environments and to review the current state-of-the-art of single particle inductively coupled plasma mass spectrometry (SP-ICP-MS) approaches to detect and characterise $\mathrm{TiO}_{2}$ nanoparticles in aqueous media. Furthermore, it critically analyses the capability of existing fate and transport models to predict environmental $\mathrm{TiO}_{2}$ levels. Four particle and environmental key factors that govern the fate and behaviour of $\mathrm{TiO}_{2}$ in aqueous environments are identified. A comparison of SP-ICP-MS studies reveals that it remains challenging to detect and characterise engineered $\mathrm{TiO}_{2}$ nanoparticles in various matrices and highlights the need for the development of new SP-ICP-MS pre-treatment and analysis approaches. This review shows that modelling studies are an essential addition to experimental studies, but they still lack in spatial and temporal resolution and mostly exclude surface transformation processes. Finally, this study identifies the use of Bayesian Network-based models as an underexplored but promising modelling tool to overcome data uncertainties and incorporates interconnected variables.
\end{abstract}

Keywords: nano- $\mathrm{TiO}_{2}$; inorganic UV filter; sunscreen; surface coating deterioration; SP-ICP-MS; fate and transport modelling; risk assessment; Bayesian network; aquatic pollution

\section{Introduction}

Skin cancer (melanoma and non-melanoma) is one of the most common cancer types worldwide [1,2]. To reduce the risks of it, public awareness campaigns that promote the importance of the use of broad-spectrum (280-400 nm) ultraviolet radiation (UVR) protection have increased over the last few decades. These campaigns have been encouraging the use of sunscreen as an important protection measure. As a result, the use of sunscreen globally has increased significantly. For example, due to the Australian campaign 'SunSmart', sunscreen use has risen by $25 \%$ over the past 30 years [3]. 
However, with the increased application of sunscreen, there are concerns regarding the inevitable release and environmental consequences of sunscreen residues. These concerns are further cemented because the full extent of potential environmental consequences has not yet been clarified. Based on the risks to human and environmental health, some governments have started introducing national bans on certain organic ultraviolet (UV) filters [4]. Subsequently, inorganic UV filters such as titanium dioxide $\left(\mathrm{TiO}_{2}\right)$ or zinc oxide $(\mathrm{ZnO})$ gained popularity as the 'reef-safe' and 'eco-friendly' alternatives. However, there is a continued debate on whether inorganic UV filters, especially in nanoparticle (NP) form, are safe to use or whether they pose a risk to humans and the environment, particularly when used for longer periods.

Sobek et al. [5] classified $\mathrm{TiO}_{2}$ as toxic to aquatic life with long-lasting effects based on the regulation on classification, labelling, and packaging (CLP) of substances and mixtures. Furthermore, the International Agency for Research on Cancer [6] has categorised $\mathrm{TiO}_{2}$ as possibly carcinogenic (Group 2B).

Besides being potentially cytotoxic and genotoxic $[7,8], \mathrm{TiO}_{2}$ is a known photocatalyst and is capable of generating reactive oxygen species (ROS) such as hydrogen peroxide $\left(\mathrm{H}_{2} \mathrm{O}_{2}\right)$, hydroxyl radicals $(\mathrm{OH} \cdot)$, or singlet oxygen $\left({ }^{1} \mathrm{O}_{2}\right)$. This is another drawback of $\mathrm{TiO}_{2}$, as ROS can induce oxidative stress and catalyse DNA damage [9,10]. To reduce the catalytic activity, recent studies have been focusing on reducing the ROS production by either doping with other elements or by coating the synthesised NP [11]. However, previous studies have shown that these coatings can (partially) deteriorate when subject to some exposure conditions [12,13], affecting both the degree of toxicity and the fate of the environmental.

Even though the number of (eco-)toxicity studies has substantially increased over the last few decades, experimental studies that conduct long-term investigations are still limited [14] and rarely consider real environmental conditions as an exposure scenario [15]. Furthermore, Minetto et al. [15] reported that, as studies do not follow a standardised experimental procedure, results are rarely comparable and reproducible. Study outcomes of the same core material may also be inconsistent due to the effect of different particle properties, such as particle size (PS), shape, surface coating on the (eco-)toxicity, and the different NP behaviour in various environmental or laboratory settings [16,17]. A recent study published in 2021 reports that solar radiation significantly increases the ecotoxicity of nano- $\mathrm{TiO}_{2}$ in aquatic environments, particularly if organic UV filters are simultaneously present [18]. Consequently, eco-toxicologists need a better understanding of the particle behaviour to interpret the results appropriately and to develop innovative toxicity studies.

In addition to the common eco-toxicological dose descriptors, more behavioural toxicological endpoints are needed to identify potential risks; for example, the exposure to $\mathrm{TiO}_{2}$ caused substantial disruptions in the swimming behaviour of clownfish, whereas their mortality rate only slightly increased [19]. Another aspect that is understudied is the effect of chronic exposure to by-products of aged nano- $\mathrm{TiO}_{2}$ in aquatic organisms. For instance, Fouqueray et al. [20] observed a decrease in growth and reproduction of Daphnia Magna that was fed nano- $\mathrm{TiO}_{2}$ residue-contaminated algae over 21 days. Such observations also raise concerns regarding the potential for trophic transfer and bioaccumulation in the food chain.

Based on a literature search, algae were the most vulnerable group of aquatic organisms when exposed to nano- $\mathrm{TiO}_{2}$ with a no observed effect concentration (NOEC) of $<0.2 \mathrm{mg} \mathrm{TiO}_{2} / \mathrm{L}$ [21]. The NOEC can be converted to the predicted no-effect concentration (PNEC) by dividing the NOEC by an assessment factor (AF). Estimates of the PNEC are essential for carrying out an environmental risk assessment (ERA). Due to the limited number of long-term studies, applying an AF of 100-1000 is considered conservative and reasonable [22]. Based on these estimates, the PNEC value is $0.2-2 \mu \mathrm{g} / \mathrm{L}$, which is consistent with the findings of previous studies, which have produced values such as $1 \mu \mathrm{g} / \mathrm{L}$ [23], $16 \mu \mathrm{g} / \mathrm{L}$ [24], and $20 \mu \mathrm{g} / \mathrm{L}$ [25]. 
Besides the PNEC value, a precise determination of the predicted environmental concentration (PEC) of nano- $\mathrm{TiO}_{2}$ is essential for an accurate ERA. The PEC can be derived from both analytical and modelling studies; however, neither approach has, so far, been able to resolve the variability of PEC in different environments in detail [26]. This can partly be attributed to challenges associated with appropriate and robust analytical methods but also to the complexity and breadth of this emergent field. As analytical techniques are not able to explain all real-scenario observations, modelling approaches are considered a critical and complementary tool to fill the knowledge gaps [27]. Understanding the behaviour of nano- $\mathrm{TiO}_{2}$ in diverse environments is important for building a robust model. However, this can rarely be done through analytical studies, and, therefore, it necessitates hybrid approaches to overcome these challenges.

This review aims to address these challenges by (1) identifying potential exposure pathways of nano- $\mathrm{TiO}_{2}$ to the environment; (2) discussing the impact of individual particles and environmental factors on the fate and behaviour of nano- $\mathrm{TiO}_{2}$; (3) reviewing relevant experimental studies that examined the fate and behaviour processes of nano- $\mathrm{TiO}_{2}$ in selected environmental compartments; (4) analysing the suitability of single particle inductively coupled plasma mass spectrometry (SP-ICP-MS) to measure nano- $\mathrm{TiO}_{2}$ in the environment; and (5) evaluating the potential use of modelling methods to support analytical approaches.

It should be noted that nano- $\mathrm{TiO}_{2}$ is released into the hydrosphere from multiple sources and poses a potentially serious risk to aquatic environments. Although this review mainly focuses on $\mathrm{TiO}_{2}$ released from sunscreens, it also discusses the recent developments in approaches and techniques for identifying and monitoring the presence and fate of engineered nano- $\mathrm{TiO}_{2}$, which has relevance to researchers seeking better understanding of nano- $\mathrm{TiO}_{2}$ from these varied contributing sources.

\section{Distribution and Fate of Nano- $\mathrm{TiO}_{2}$ in the Environment}

Owing to its unique properties, nano- $\mathrm{TiO}_{2}$ is applied widely, including to cosmetics $(59 \%)$, paint and coatings $(13 \%)$, electronics $(7 \%)$, cleaning agents $(6 \%)$, filters $(6 \%)$, plastics $(4 \%)$, and wastewater $(\mathrm{WW})$ disinfectants $(<1 \%)$ [28]. It is estimated that sunscreens make up about $25 \%$ of the nano- $\mathrm{TiO}_{2}$ market share [29]. Consequently, sunscreens are likely to be one of the significant sources of nano- $\mathrm{TiO}_{2}$ released into the environment.

\subsection{Exposure Pathways to the Environment}

To evaluate the environmental risk of nano- $\mathrm{TiO}_{2}$ in sunscreen, it is helpful to determine the potential input and distribution channels. Figure 1 illustrates the exposure pathways of nano- $\mathrm{TiO}_{2}$ from sunscreens to the environment. The release of nano- $\mathrm{TiO}_{2}$ into aqueous environments is likely to occur once users enter the water after applying sunscreen. Depending on the viscosity of the formulation, $10-40 \%$ of NPs are released from the initially applied sunscreen [30].

The remaining nano- $\mathrm{TiO}_{2}$ residues enter the WW stream after being washed off in the shower. In the WW treatment plants (WWTPs), it is estimated that, on average, approximately $34 \%$ and $87 \%$ of nano- $\mathrm{TiO}_{2}$ is removed from the primary and secondary settling tanks, respectively [31]. However, since sewage sludge is often used as soil fertiliser, nano- $\mathrm{TiO}_{2}$ could contaminate agricultural soils and may even leach into the groundwater, consequently re-entering the aqueous environment $[32,33]$. The leaching behaviour greatly depends on the nature of the soil and has not been studied adequately [14,34]. In one study, Dulger et al. [35] investigated the leaching potential of nano- $\mathrm{TiO}_{2}$ in landfills and concluded that about $81-97 \%$ of the introduced nano- $\mathrm{TiO}_{2}$ is retained on the solid surface. However, to date, the extent to which nano- $\mathrm{TiO}_{2}$ leaches from sewage sludge remains unclear.

Another exposure pathway that is only occasionally considered in the literature is the washing off of sunscreen during activities in swimming pool water (SPW). However, this should be considered as part of realistic and regionalised calculations as the number of privately owned swimming pools continues to increase steadily. For example, in Australia, 
residential pool ownership has risen from $12 \%$ to $13 \%$ over the last three years [36], and it is expected that sunscreen is used as most of these swimming pools are outdoors. Therefore, nano- $\mathrm{TiO}_{2}$ released from sunscreen is likely to be found in (1) diverse aqueous media (e.g., SPW, natural waters); (2) WWTPs; (3) sewage sludge; (4) agriculture soils; and (5) landfill. This review paper primarily focuses on the fate and behaviour of nano- $\mathrm{TiO}_{2}$ in the first of these environments, the aqueous media.

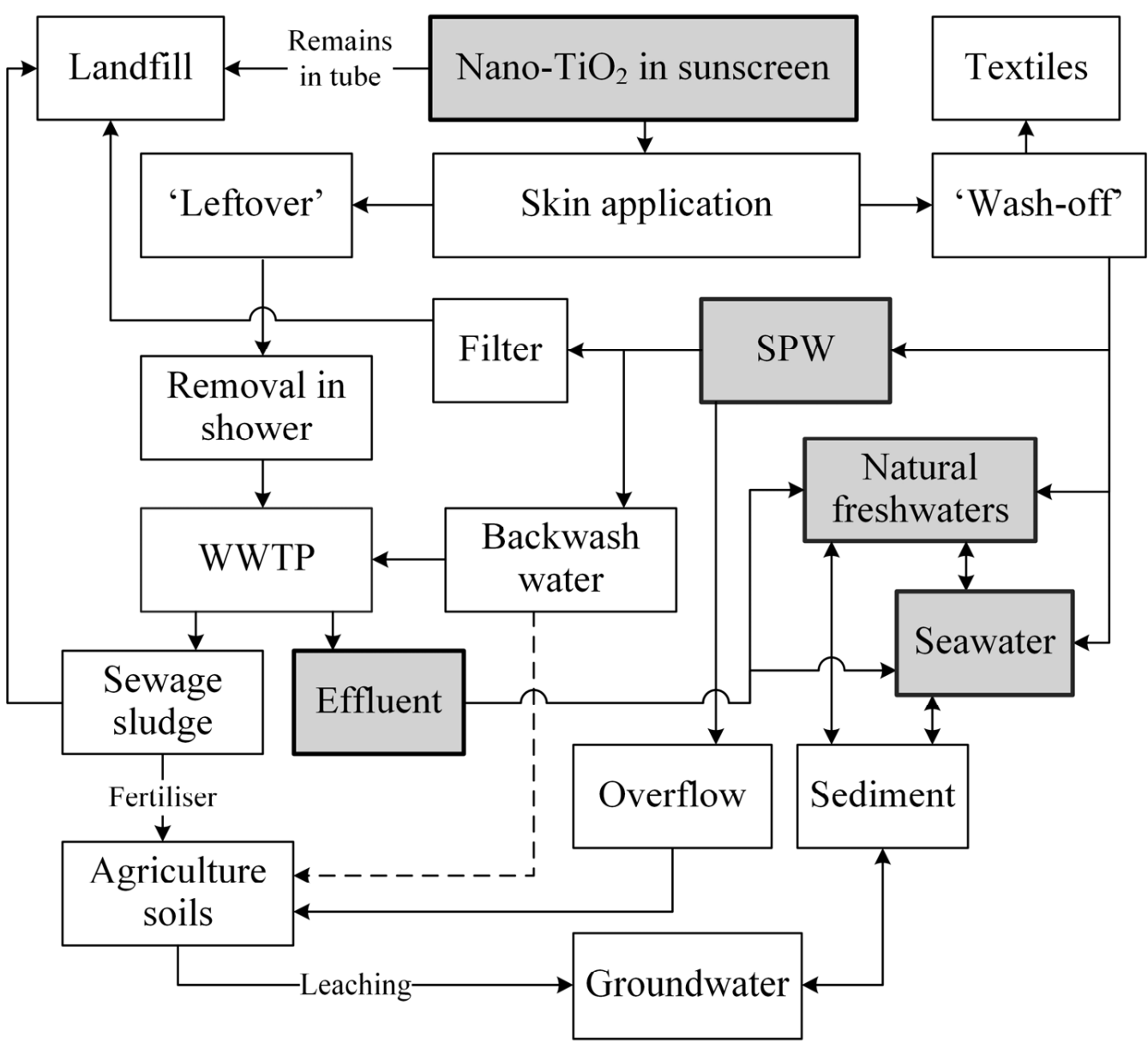

Figure 1. Routes of entry of nano- $\mathrm{TiO}_{2}$ contained in sunscreens into the environment; adopted from Musee [23]. The grey boxes represent the focus of this research.

\subsection{Behaviour and Fate of Nano-TiO}

Understanding the particle behaviour and fate of nano- $\mathrm{TiO}_{2}$ helps to predict its concentration and state in the environment, which then determine the risk and impact on the environment. The following three sections discuss the influence of selected nano- $\mathrm{TiO}_{2}$ properties and environmental conditions on the particle behaviour and fate and conclude with an overview of experimental research findings.

\subsubsection{The Pivotal Role of Nano- $\mathrm{TiO}_{2}$ Characteristics}

Commercially available nano- $\mathrm{TiO}_{2}$ suitable for incorporating into sunscreen formulas varies in its characteristics such as PS, shape, crystalline phase, core composition, and surface properties. These physicochemical properties can significantly affect the behaviour, fate, and (eco)toxicity of nano- $\mathrm{TiO}_{2}$ as discussed below.

Due to manufacturing processes, the $\mathrm{PS}$ of $\mathrm{TiO}_{2}$ can vary in precision and accuracy, and thus, is usually high in polydispersity that may extend beyond the nanometre scale. However, the PS for obtaining a transparent sunscreen with adequate UV attenuation typically ranges from $10-40 \mathrm{~nm}[37,38]$. An increase in PS shifts the UV attenuation capability 
of $\mathrm{TiO}_{2}$ to longer wavelengths, and, hence, influences the range of UV protection [39]. Therefore, to maintain the desired UV attenuation, the tendency of smaller particles to form aggregates and agglomerates should be prevented [40]. However, smaller particles exhibit higher toxicity [41] and are even able to penetrate human skin and enter the bloodstream [42]. Similarly, Pelclova et al. [43] detected nano- $\mathrm{TiO}_{2}(<14 \mathrm{~nm})$ in biological fluids such as plasma and urine due to the absorption of nano- $\mathrm{TiO}_{2}$ through the human skin. Moreover, the photocatalytic activity of $\mathrm{TiO}_{2}$ is size-dependent as a result of charge-carrier dynamics, light absorption and scattering efficiency, as well as the specific surface area [44].

The particle shape of nano- $\mathrm{TiO}_{2}$ found in sunscreens varies from spherical, elongated (rod-shaped, needle-shaped) to ellipsoidal forms [45,46]. The NP shape also affects the toxicity, including by influencing the rate of particle uptake by primary human immune cells [47]. However, to date, studies reporting correlations between particle shape and environmental or human health risks are limited [48,49].

$\mathrm{TiO}_{2}$ can exist in three crystalline forms: anatase, rutile, and brookite [32]. However, only pure forms of rutile or anatase or a mixture of both are incorporated in sunscreens $[46,50]$. Among other characteristics, the crystal structures determine the potential toxicity of $\mathrm{TiO}_{2}$. For example, anatase and anatase mixtures are under suspicion of causing oxidative stress or cytotoxicity [51,52]. Despite these concerns, many sunscreens often still contain anatase [46].

The core composition of nano- $\mathrm{TiO}_{2}$ can be altered by metal doping with, for example, manganese $(\mathrm{Mg})$, vanadium $(\mathrm{V})$, or iron $(\mathrm{Fe})$ [32]. Variations in the core composition can change the overall physicochemical properties, and, thus, impact the holistic behaviour and fate of the NPs in the environment $[53,54]$. The aim of structural modifications is primarily to lower or quench the generation of ROS, which reduces the phototoxicity of nano- $\mathrm{TiO}_{2}[55,56]$.

The surface chemistry is a key factor that influences nano- $\mathrm{TiO}_{2}$ characteristics such as photocatalytic activity or dispersibility [57]. As smaller particles tend to aggregate readily [40], surface coatings are frequently applied to sustain particle stability in the sunscreen [58]. The formulation type of a sunscreen determines what surface treatment to use to promote dispersibility and particle stabilisation. Oil-in-water $(\mathrm{O} / \mathrm{W})$ types allow for the incorporation and stabilisation of nano- $\mathrm{TiO}_{2}$ as is, whereas water-in-oil $(\mathrm{W} / \mathrm{O})$ types usually require organic coatings that change the hydrophilic character of the surface to a lipophilic one [59]. The photocatalytic effect has also been suppressed by applying inorganic layers such as aluminium oxide $\mathrm{Al}_{2} \mathrm{O}_{3}$, aluminium hydroxide $\mathrm{Al}(\mathrm{OH})_{3}$, (hydrated) silica $\mathrm{SiO}_{2}$, or a combination of the above [60,61] to passivate the $\mathrm{TiO}_{2}$ surface. Additionally, they can be combined with organic surface treatments to improve the dispersibility in W/O types [62].

However, surface treatments can wear out over time and are susceptible to alteration or degradation when exposed to diverse media. Therefore, previous studies have attempted to examine the influence of extrinsic factors. For example, if hydrophobic organic or polymeric coatings such as polydimethylsiloxane (PDMS) are exposed to $\mathrm{pH}$ neutral ultrapure water, over time (hours to days), the PDMS layer completely dissolves and the particle surface becomes hydrophilic [63]. This promotes the dispersibility of nano- $\mathrm{TiO}_{2}$ in aqueous environments and the formation of stable colloids. Similarly, Auffan et al. [13] observed a complete dissolution of the PDMS layer and a partial deterioration of the $\mathrm{Al}(\mathrm{OH})_{3}$ layer in contact with water $(\mathrm{pH}=5)$. On the contrary, Wu et al. [62] found that layers of a structurally related polymer (hydrogen dimethicone) do not dissolve in water and remain hydrophobic even after sonification. However, if $1 \%(v / v)$ organic solvent such as ethanol (EtOH) was added, the organic coating dissolved.

Nevertheless, the $\mathrm{Al}(\mathrm{OH})_{3}$ layer seems to retain its protective properties when in contact with deionised (DI) water, as the coating still inhibits the generation of ROS [13]. However, if exposed to SPW or seawater, a significant redistribution of the $\mathrm{Al}(\mathrm{OH})_{3}$ coating occurs $[12,64]$. Herein, it was found that especially chlorine $\left(\mathrm{HOCl} / \mathrm{OCl}^{-}\right)$was responsible for diminishing the coating's integrity [65]. The redistribution of the $\mathrm{Al}(\mathrm{OH})_{3}$ coating also 
resulted in enhanced photocatalytic activity compared to unaged nano- $\mathrm{TiO}_{2}$ [12]. According to Al-Abed et al. [12], the layer thickness is critical for the prevention of photocatalytic activities. Moreover, previous studies have indicated that UVR could also affect the integrity of the $\mathrm{Al}(\mathrm{OH})_{3}$ layer [62]. The damage or loss of protective surface layers not only influences transport or fate processes but also restores the photoactivity of nano- $\mathrm{TiO}_{2}[66]$ and is therefore undesirable.

To overcome these shortcomings and to ensure the sunscreen endures the harsh environmental conditions, new surface treatments (Table 1) have been developed in recent years. Table 1 summarises recent findings that primarily refer to novel organic and $\mathrm{TiO}_{2}$ hybrid nanostructures or the incorporation of $\mathrm{TiO}_{2}$ into inorganic auxiliary structures. Table 1 only consists of surface treatments that would seem viable for commercial use. We defined a surface treatment as viable if it had a realistic number of manufacturing process steps.

Table 1. Novel surface treatments that intend safe usage of $\mathrm{TiO}_{2}$ as $\mathrm{UV}$ filter in cosmetic formulations.

\begin{tabular}{ccc}
\hline & Surface Treatment & Benefits \\
\hline $\mathrm{O}$ & $\begin{array}{c}\text { Lignin } / \mathrm{TiO}_{2} \text { nanocomposites } \\
\text { Previous study with similar approach: } \\
\text { Encapsulation of } \mathrm{TiO}_{2} \text { by different types } \\
\text { of lignin [67] }\end{array}$ & $\begin{array}{c}\text { Good dispersibility; high sun } \\
\text { protection factor (SPF) }\end{array}$ \\
R: Chemically coated lignosulfonate & $\begin{array}{c}\mathrm{O}-\mathrm{C}-\mathrm{R} \\
\text { [68] }\end{array}$ & \\
\hline
\end{tabular}

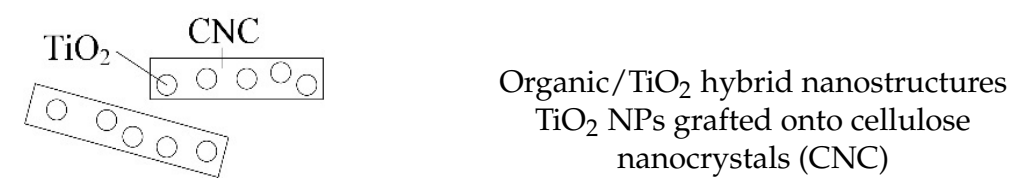

High SPF; in o/w: replaces surfactant in formulation

CNC: Cellulose nanocrystals

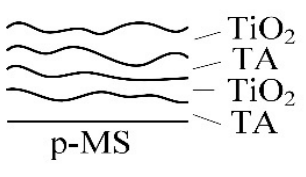

TA: Tannic acid p-MS: porous polymer microspheres
Tannin/ $\mathrm{TiO}_{2}$ multilayers on p-MS

Deposition on porous

polymethylmethacrylate (PMMA) microspheres

Reduced ROS; high SPF

Layer-by-layer assembly of $\mathrm{TiO}_{2}$ and TA via ligand-to-metal complexation

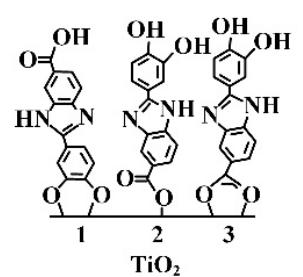

$\mathrm{TiO}_{2}$
Surface functionalisation with Oxisol Oxisol: Polyphenol dihydroxyphenyl benzimidazole carboxylic acid

Addition mechanism of Oxisol to $\mathrm{TiO}_{2}$ Steric stabilisation likely
Reduced ROS; reduced photocatalytic activity; high SPF
Comparable SPF; no photocatalytic activity
MMC: Mesoporous magnesium carbonate cluster

$$
\begin{gathered}
\begin{array}{c}
\text { CROSS-POLYMER } \\
\text { silicate } \\
\text { polyalkylsilsesquioxane } \\
\text { polydimethylsiloxane }
\end{array} \\
\mathrm{TiO}_{2}
\end{gathered}
$$
amorphous MMC structure

(+ dimethicone layer)

\section{$\mathrm{MMC}-\mathrm{TiO}_{2}-\mathrm{ZnO}$}

\section{Incorporation of $\mathrm{TiO}_{2}$ and $\mathrm{ZnO}$ into an}


Table 1. Cont.

\begin{tabular}{|c|c|c|c|}
\hline \multicolumn{2}{|c|}{ Surface Treatment } & \multirow[b]{2}{*}{$\begin{array}{l}\text { Enhanced UV attenuation; } \\
\text { reduced photocatalytic } \\
\text { activity; biocompatible }\end{array}$} & \multirow{2}{*}{$\begin{array}{c}\text { Reference } \\
\text { [74] }\end{array}$} \\
\hline 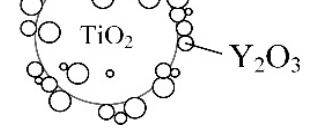 & $\begin{array}{c}\mathrm{Y}_{2} \mathrm{O}_{3} / \mathrm{TiO}_{2} \text { nanocomposites } \\
\text { Deposition of } \mathrm{Y}_{2} \mathrm{O}_{3} \text { onto } \mathrm{TiO}_{2} \\
\text { Uniform } \mathrm{Y}_{2} \mathrm{O}_{3} \text { coating }\end{array}$ & & \\
\hline $\mathrm{Y}_{2} \mathrm{O}_{3}$ : Yttrium oxide & & & \\
\hline $20{ }_{0}^{20} \mathrm{TiO}_{2} \mathrm{Q} \mathrm{CeO}_{2}$ & $\begin{array}{c}\mathrm{CeO}_{2} / \mathrm{TiO}_{2} \text { nanocomposites } \\
\mathrm{CeO}_{2} \text { nanodot encrusted } \mathrm{TiO}_{2} \text { NPs }\end{array}$ & $\begin{array}{l}\text { Reduced photocatalytic } \\
\text { activity; biocompatible }\end{array}$ & [75] \\
\hline $\mathrm{CeO}_{2}$ : Cerium dioxide & & & \\
\hline
\end{tabular}

Importantly, even though new surface treatments may improve the performance of $\mathrm{TiO}_{2}$-based UV filters, there still remain uncertainties around their ecotoxicity and fate. Given that the surface coatings are largely responsible for the fate, exposure and hazard of nano- $\mathrm{TiO}_{2}$, often independently of the $\mathrm{TiO}_{2}$ core [57], it is critical that new coatings and formulations are assessed for their (eco)toxicity before or as they become commercialised and mass-produced.

\subsubsection{The Influence of Environmental Conditions}

Assessing the influence of environmental factors such as $\mathrm{pH}$, ionic strength (IS), and composition and occurrence of natural organic matter (NOM) is essential when evaluating the behaviour of nano- $\mathrm{TiO}_{2}$ in real environments. The impact of these factors on the colloidal stability can often be explained by the Derjaguin-Landau-Verwey-Overbeek (DLVO) theory [76,77] that considers the combined effects of van der Waals (VDW) attraction and electrical double layer (EDL) repulsion. However, in natural environmental systems, nano- $\mathrm{TiO}_{2}$ is likely to adsorb water molecules and macromolecules, such as NOM at the interface, which results in further interparticle forces (e.g., hydration or steric interactions). Therefore, the assessment of colloidal stability should also include non-DLVO forces. Based on experimental results (Table 2), three key factors were identified that substantially affect the behaviour of nano- $\mathrm{TiO}_{2}$.

Firstly, the interplay between the $\mathrm{pH}$ of the media and the isoelectric point (IEP) of $\mathrm{TiO}_{2}$ significantly influences the colloidal stability of nano- $\mathrm{TiO}_{2}$. That is, if the $\mathrm{pH}$ is close to the IEP, the surface charge changes sign with only small $\mathrm{pH}$ variations, considerably reducing the colloidal stability due to the annihilation of electrostatic repulsion [63]. Conversely, the NPs are considered stable if the zeta potential exceeds $\pm 30 \mathrm{mV}$ at the given $\mathrm{pH}$ of the environment [78].

Recent research has established that the IEPs of $\mathrm{TiO}_{2} \mathrm{NPs}$ extracted from commercial sunscreens were all below 4.6 [45]. As the $\mathrm{pH}$ in natural waters is between 6-9 [79], the surface charge of $\mathrm{TiO}_{2} \mathrm{NP}$ is expected to be negative. This promotes the stabilisation of nano- $\mathrm{TiO}_{2}$ due to EDL repulsion but only if no further environmental factors affect the colloidal stability.

The IEP of $\mathrm{TiO}_{2}$ differs depending on its crystalline structure (e.g., 3.5 for anatase and 6.5 for rutile) [80] and can change as a result of the application of additional coatings. For example, the IEP decreases if coated with $\mathrm{SiO}_{2}$ (IEP of 2.0) or increases if coated with $\mathrm{Al}_{2} \mathrm{O}_{3}$ or $\mathrm{Al}(\mathrm{OH})_{3}$ (IEP of 9 or 6.8, respectively) [80].These alterations can affect the fate and behaviour of nano- $\mathrm{TiO}_{2}$ in the environment. However, as the colloidal stability not only depends on the IEP as a function of the $\mathrm{pH}$ but also on the general chemistry of the environment, it is assumed that the primary aim of novel coatings is to reduce the photocatalytic activity rather than to influence the IEP of nano- $\mathrm{TiO}_{2}$. 
Nevertheless, information on both the $\mathrm{pH}$ and IEP in combination with other influencing factors can aid in describing and predicting the fate and behaviour of nano- $\mathrm{TiO}_{2}$. For example, Englehart et al. [81] observed that a polymer sunscreen additive decreased the initial IEP of $\mathrm{TiO}_{2}$ from 6.3 to less than 5, which entailed a diminished capacity of water-saturated porous media (e.g., sand) to retain nano- $\mathrm{TiO}_{2}$ at environmentally relevant $\mathrm{pH}$ values.

Secondly, the IS and the type of ion also affect the colloidal stability of nano- $\mathrm{TiO}_{2}$ in diverse environments. Zhang et al. [82] investigated the impact of ions such as $\mathrm{Na}^{+}, \mathrm{Ca}^{2+}$, $\mathrm{Cl}^{-}$, and $\mathrm{PO}_{4}{ }^{3-}$ at a high and low IS on the stability of nano-TiO ${ }_{2}$. They observed that at a low IS the surface complexation with $\mathrm{PO}_{4}{ }^{3-}$ contributed to an elevated negative surface charge, thus promoting the NP stability due to the electrostatic repulsion. However, with an increasing IS, the negative surface charge of nano- $\mathrm{TiO}_{2}$ could no longer increase as the number of complexation sites on the particle surface was limited and already used up with $\mathrm{PO}_{4}{ }^{3-}$. Consequently, at higher IS, the high compression of the EDL can overcome the limited electrostatic repulsion, leading to a destabilisation of the nano- $\mathrm{TiO}_{2}$. Furthermore, they observed that $\mathrm{Na}^{+}$and $\mathrm{Ca}^{2+}$ were equally able to destabilise nano- $\mathrm{TiO}_{2}$ at the same IS, while some cations, especially divalent cations like $\mathrm{Ca}^{2+}$, were able to induce bridging of two negatively charged surfaces [83] and promote the formation of aggregates.

Thirdly, the type and concentration of NOM significantly affect the colloidal stability of nano- $\mathrm{TiO}_{2}$ as the adsorption of polymers at the interface can, for instance, lead to attractive (polymer bridging) or repulsive steric interactions. In the literature, researchers investigating the influence of different types of NOM on colloidal stability have primarily focused on fulvic (FA) and humic acids (HA). Even though both acids can adsorb onto the NP surface, the adsorption percentage of HA has been shown to be twice as much in water compared to FA due to its greater hydrophobicity [83]. Therefore, HA hindered the particle aggregation more effectively than FA. However, Luo et al.'s study observed that this only applies to media with an IS lower than the critical coagulation concentration (CCC) of nano- $\mathrm{TiO}_{2}$. In the case of IS $>\mathrm{CCC}$, the presence of $\mathrm{HA}$ promotes the nano- $\mathrm{TiO}_{2}$ aggregation even more. As reported by Slomberg et al. [84], nano- $\mathrm{TiO}_{2}$ prefers to interact with anionic NOM with high or medium molecular weights.

The assessment of the impact of NOM should always consider the whole environmental matrix, as this significantly influences the experimental outcome. At high IS, nano- $\mathrm{TiO}_{2}$ can aggregate due to reduced repulsive forces as a result of the EDL compression [85]. However, this aggregation behaviour can be modified or reduced in the presence of NOM due to electrostatic and steric forces [83]. For example, Labille et al. [86] studied the heteroaggregation potential of $\mathrm{TiO}_{2}$ and smectite clay considering the influence of $\mathrm{pH}$, IS, and NOM. Regardless of whether the $\mathrm{pH}$ is above or below the IEP of the original $\mathrm{TiO}_{2} \mathrm{NPs}$, the adsorption of $\mathrm{NOM}$ on the surface of clay and $\mathrm{TiO}_{2}$ supports the colloidal stability even at a high IS $(0.1 \mathrm{M} \mathrm{NaCl})$. However, Luo et al. [83] observed the destabilisation of nano- $\mathrm{TiO}_{2}$ in the presence of NOM at pH $8>$ IEP and an even lower IS $\left(>0.005 \mathrm{M} \mathrm{CaCl}_{2}\right)$, which is likely explained by the ability of $\mathrm{Ca}^{2+}$ ions to link two negatively charged surfaces-in this case, $\mathrm{NOM}$ and nano- $\mathrm{TiO}_{2}$ - and thus enhance aggregation.

\subsubsection{Experimentally Observed Behaviour and Fate Processes}

Having considered the key influential factors separately, this section focuses on the experimentally observed behaviour and fate processes that were described in the context of specific environments. Overall, the environmental processes (Figure 2) that dominantly affected the behaviour and fate of nano- $\mathrm{TiO}_{2}$ were (1) transport processes (sedimentation, resuspension); (2) transformation processes (surface transformation, photolysis, homo/heteroaggregation and/or -agglomeration); and (3) bioaccumulation (transport vector for heavy metals). Table 2 summarises the experimental findings from the past decade that help to understand the fate and behaviour of nano- $\mathrm{TiO}_{2}$ in various matrices. 


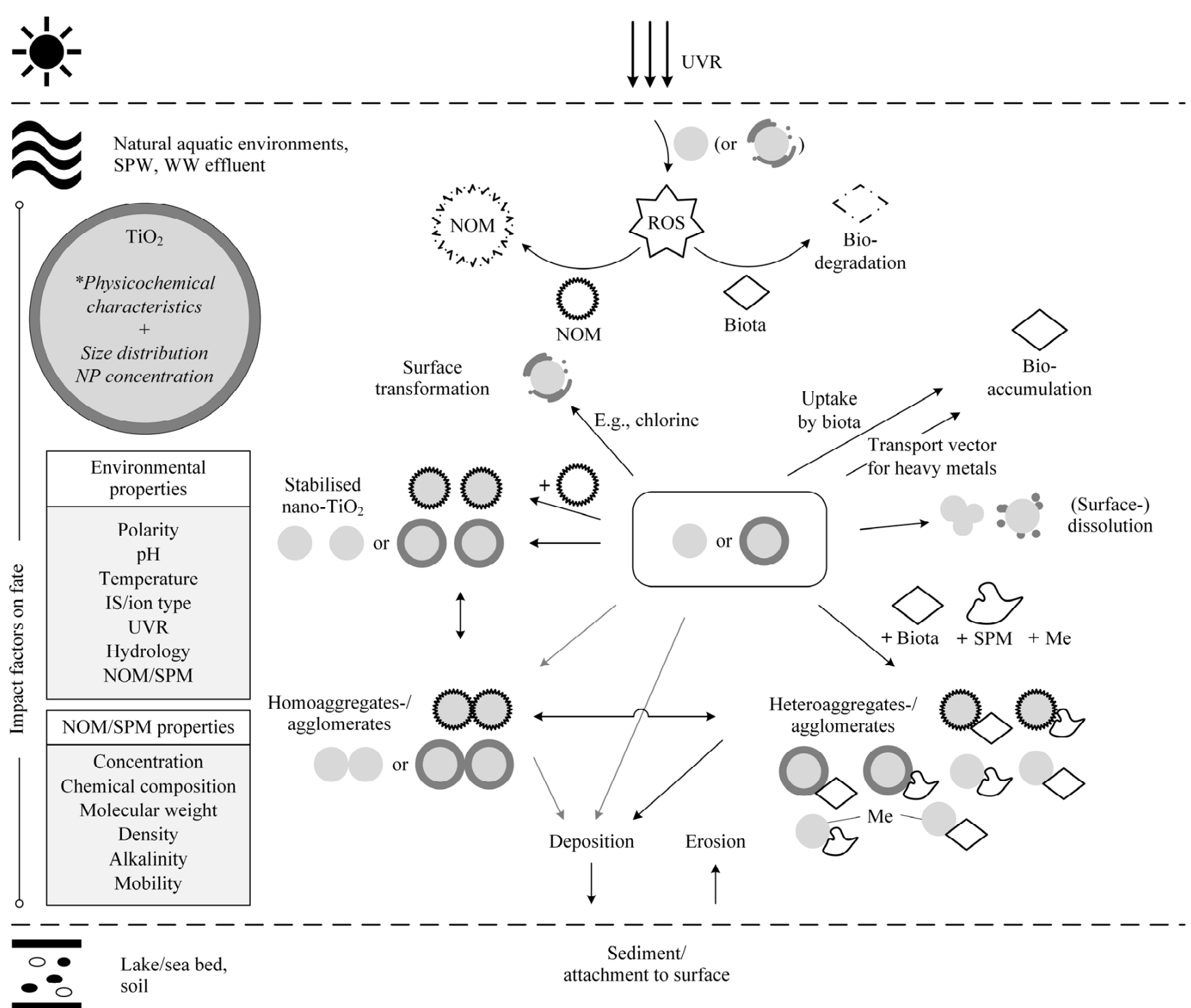

Figure 2. Schematic view of potential transformation, transport, and bioaccumulation processes in an aqueous environment.

Table 2. Overview of experimental studies that have investigated behaviour and fate processes in sunscreen, SPW, and natural aquatic environments.

\begin{tabular}{|c|c|c|c|c|}
\hline Matrix & Exposure & Predominant Processes & Implication & Reference \\
\hline \multirow{5}{*}{ Sunscreen } & $\begin{array}{l}\text { Oxybenzone, avobenzone, } \\
\text { octyl methoxycinnamate }\end{array}$ & $\begin{array}{c}\text { Photodegradation of organic } \\
\text { UV filters }\end{array}$ & Joint toxicity & {$[87,88]$} \\
\hline & $\begin{array}{l}\text { Acrylates/C10-30 alkyl acrylate } \\
\text { cross-polymer (stabilising agent) }\end{array}$ & $\begin{array}{l}\text { Adsorption of the polymer, } \\
\text { decrease IEP from } 6.3 \text { to }<5\end{array}$ & $\begin{array}{l}\text { Electrostatic NP stabilization, } \\
\text { enhanced NP mobility at } \\
\text { environmentally relevant } \mathrm{pH} \\
\text { values }(6-9) \text {, reduced } \\
\text { filtration efficiency }\end{array}$ & [81] \\
\hline & EtOH, UVR & $\begin{array}{l}\text { Partial degradation of the } \\
\text { hydrogen dimethicone coating } \\
\text { due to the dissolving ability } \\
\text { of EtOH }\end{array}$ & $\begin{array}{l}\text { Photodegradation of the organic } \\
\text { and subjacent layer: } \mathrm{Al}(\mathrm{OH})_{3}\end{array}$ & [62] \\
\hline & $\begin{array}{l}\text { Hydroxy acids (Salicylic/ } \\
\text { citric acid) }\end{array}$ & Biomolecular chelation of $\mathrm{Ti}^{4+}$ & $\begin{array}{l}\text { Induced solubilization } \\
\text { by chelation }\end{array}$ & {$[8]$} \\
\hline & Additional NPs in formulation & & Higher phototoxicity & [14] \\
\hline
\end{tabular}


Table 2. Cont.

\begin{tabular}{|c|c|c|c|c|}
\hline Matrix & Exposure & Predominant Processes & Implication & Reference \\
\hline \multirow{6}{*}{ SPW } & $\begin{array}{l}\text { Calcium sulphate dihydrate } \\
\left(\mathrm{CaSO}_{4} \bullet 2 \mathrm{H}_{2} \mathrm{O}\right)\end{array}$ & $\begin{array}{l}\text { Adsorption of } \mathrm{Ca}^{2+} \text { increased } \\
\text { zeta potential }\end{array}$ & Reduced colloidal stability & [65] \\
\hline & \multirow{5}{*}{$\begin{array}{c}\text { Potassium cetyl phosphate } \\
\left(\mathrm{C}_{16} \mathrm{H}_{34} \mathrm{KO}_{4} \mathrm{P}, \mathrm{PCP}\right) \text { and chlorine }\end{array}$} & $\begin{array}{l}\text { Surface transformation, } \\
\text { redistribution of the } \mathrm{Al}(\mathrm{OH})_{3} \\
\text { protective layer }\end{array}$ & $\begin{array}{l}\text { Reduced agglomeration, } \\
\text { formation of porous aggregates, } \\
\text { depletion of } \mathrm{Al}(\mathrm{OH})_{3} \text { coating } \\
\text { from the nano- } \mathrm{TiO}_{2} \text { surface }\end{array}$ & [65] \\
\hline & & $\begin{array}{l}\text { Surface transformation, } \\
\text { redistribution of the } \mathrm{Al}(\mathrm{OH})_{3} \\
\text { protective layer }\end{array}$ & $\begin{array}{c}\text { Depletion of } \mathrm{Al}(\mathrm{OH})_{3} \text { coating } \\
\text { from the nano- } \mathrm{TiO}_{2} \text { surface, } \\
\text { photocatalytic formation of } \\
\text { hydroxyl radicals }(\bullet \mathrm{OH})\end{array}$ & {$[12,64]$} \\
\hline & & $\begin{array}{c}\text { Degradation of } \mathrm{PCP} \text { releases } \\
\mathrm{PO}_{4}{ }^{3-} \text { ions, subsequent } \\
\text { formation of } \mathrm{AlPO}_{4} \text { precipitates }\end{array}$ & \multirow[t]{3}{*}{$\begin{array}{l}\text { Acceleration of protective } \\
\text { coating depletion }\end{array}$} & [65] \\
\hline & & $\begin{array}{c}\text { Change of physicochemical } \\
\text { properties, e.g., smaller particles, } \\
\text { more spherical }\end{array}$ & & [64] \\
\hline & & $\begin{array}{l}\text { Dissolution, dominance of } \\
\text { dissolved Ti species }\end{array}$ & & [89] \\
\hline \multirow{17}{*}{$\begin{array}{l}\text { Natural } \\
\text { aquatic } \\
\text { environment }\end{array}$} & UVR, seawater & Photocatalytic reactions & $\begin{array}{l}\text { Formation of hydrogen } \\
\text { peroxide }\left(\mathrm{H}_{2} \mathrm{O}_{2}\right)\end{array}$ & [90] \\
\hline & $\begin{array}{l}\text { Shear forces (induced by } \\
\text { light, sonication) }\end{array}$ & Partial disagglomeration & Enhanced NP mobility & [91] \\
\hline & Higher ambient temperature & $\begin{array}{l}\text { Hydrodynamic } \\
\text { diameter increases }\end{array}$ & Enhanced NP sedimentation & [92] \\
\hline & $\begin{array}{l}\text { UVR + dissolved organic } \\
\text { matter (DOM) } \\
\text { (fresh-/seawater) }\end{array}$ & $\begin{array}{c}\text { Photocatalytic halogenation } \\
\text { of DOM }\end{array}$ & $\begin{array}{l}\text { Formation of organobromine/ } \\
\text {-iodine compounds }\end{array}$ & [93] \\
\hline & $\begin{array}{l}\text { Natural clay colloids (SPM) } \\
\text { (1) } \mathrm{pH}<\text { IEP } \\
\text { (2) } \mathrm{pH}>\text { IEP }\end{array}$ & $\begin{array}{c}\text { (1) Heteroaggregation (attractive } \\
\text { electrostatic forces) } \\
\text { (2) Weak affinity between } \\
\text { NPs-SPM } \\
\text { (both negatively charged) }\end{array}$ & $\begin{array}{l}\text { Enhanced } \\
\text { (1) NP aggregation } \\
\text { (2) NP stabilisation }\end{array}$ & [86] \\
\hline & HA (NOM) (pH < IEP) & $\begin{array}{l}\text { Adsorption of macromolecules } \\
\text { (1) at a low HA conc.: NP } \\
\text { surface charge neutralisation; } \\
\text { (2) at a high HA conc.: NP } \\
\text { surface charge inversion }\end{array}$ & $\begin{array}{l}\text { Enhanced } \\
\text { (1) NP aggregation } \\
\text { (2) NP stabilisation }\end{array}$ & [94] \\
\hline & $\mathrm{HA}(\mathrm{NOM})(\mathrm{pH} \approx \mathrm{IEP})$ & $\begin{array}{l}\text { Adsorption of macromolecules } \\
\text { (1) IS < CCC: Adsorption of }\end{array}$ & Induced partial disaggregation & [94] \\
\hline & $\begin{array}{l}\text { HA, FA (NOM) } \\
\quad(\mathrm{pH}>\mathrm{IEP})\end{array}$ & $\begin{array}{c}\text { macromolecules } \\
\text { (electrosteric repulsion) } \\
\text { (2) IS > CCC: EDL compression + }\end{array}$ & $\begin{array}{l}\text { Enhanced } \\
\text { (1) NP stabilisation } \\
\text { (2) NP aggregation }\end{array}$ & [83] \\
\hline & NOM (various) & $\begin{array}{l}\text { NOM entanglement } \\
\text { Adsorption of macromolecules } \\
\text { (1) low NOM conc.: } \\
\text { interparticle bridging; } \\
\text { (2) high NOM conc.: repulsive } \\
\text { steric interactions }\end{array}$ & $\begin{array}{l}\text { (1) Flocculation (dependent on } \\
\text { NOM type, sometimes salt } \\
\text { addition required) } \\
\text { (2) steric NP stabilisation }\end{array}$ & [63] \\
\hline & $\mathrm{NOM}$ & Adsorption of macromolecules & $\begin{array}{c}\text { Photosensitiser AND ROS } \\
\text { quencher (dominant) }\end{array}$ & [85] \\
\hline & $\mathrm{NaCl}$ (Seawater) + Algae & $\begin{array}{l}\text { Adsorption NPs-microalgae } \\
\text { (note: NPs-NPs) }\end{array}$ & $\begin{array}{c}\text { Intensified heteroagglomeration } \\
\text { with increase in IS } \\
\text { (note: homo-agglomeration is } \\
\text { not affected by IS) }\end{array}$ & [95] \\
\hline & $\begin{array}{l}\mathrm{NaCl} \text { (Seawater) } \\
\quad \text { (IS > CCC) }\end{array}$ & Aggregation & Induced NP aggregation & [96] \\
\hline & UVR, seawater & $\begin{array}{l}\text { Release of dissolved trace metals } \\
\text { and inorganic nutrients }\end{array}$ & $\begin{array}{l}\text { Greater bioavailability, } \\
\text { bioaccumulation }\end{array}$ & [97] \\
\hline & $\begin{array}{l}\text { Siderophore-producing } \\
\text { organisms }\end{array}$ & Biomolecular chelation of $\mathrm{Ti}^{4+}$ & & {$[8]$} \\
\hline & Presence of $\mathrm{Cu}$ & $\begin{array}{l}\text { Transport vector for heavy } \\
\text { metals, } \mathrm{Cu}^{2+} \text { absorption on } \mathrm{TiO}_{2} \\
\text { surface }\end{array}$ & Bioaccumulation of $\mathrm{Cu}$ & [98] \\
\hline & Presence of Cd, As & $\begin{array}{c}\text { Transport vector for heavy } \\
\text { metals, } \mathrm{Cd}^{2+}, \mathrm{AsO}_{4}{ }^{3-} \text { absorption } \\
\text { on } \mathrm{TiO}_{2} \text { surface }\end{array}$ & Bioaccumulation of $\mathrm{Cd}$, As & [99] \\
\hline & $\begin{array}{l}\text { Aged } \mathrm{TiO}_{2} \text { under UVR (in } \\
\text { presence of } \mathrm{Cd}^{2+} \text { ) }\end{array}$ & $\begin{array}{c}\text { Production of singlet } \\
\text { oxygen }\left({ }^{1} \mathrm{O}_{2}\right)\end{array}$ & Higher sensitivity of cells to $\mathrm{Cd}$ & [100] \\
\hline
\end{tabular}


In sunscreens, nano- $\mathrm{TiO}_{2}$ can negatively affect other sunscreen constituents such as organic UV filters. That is, the toxicity of the sunscreen can increase due to the $\mathrm{TiO}_{2}$-induced photodegradation of oxybenzone [87], avobenzone, and octyl methoxycinnamate [88], which are commonly used organic UV filters. Furthermore, the behaviour and (eco-)toxicity of nano- $\mathrm{TiO}_{2}$ in the environment can also be affected by other sunscreen components. For example, the use of the $\mathrm{C}_{10}-\mathrm{C}_{30}$ alkyl acrylate cross-polymer can increase the mobility and, thus, the concentration of nano- $\mathrm{TiO}_{2}$ in the environment [81]. Moreover, EtOH is commonly used in sunscreens to improve the compatibility and ductility of the formulation. However, EtOH dissolves the organic coating of nano- $\mathrm{TiO}_{2}$, leaving the NPs rather unstable and vulnerable to subsequent photolysis of superjacent layers [62].

Research on SPW has primarily focused on the impact of pool water ingredients on the integrity of nano- $\mathrm{TiO}_{2}$ coatings. For example, Virkutyte et al. [65] ascertained that chlorine degrades potassium cetyl phosphate (PCP), a conventional emulsifying agent in $\mathrm{O} / \mathrm{W}$ formulations, thus releasing $\mathrm{PO}_{4}{ }^{3-}$ ions. This can accelerate the deterioration of the $\mathrm{Al}(\mathrm{OH})_{3}$ layer by promoting the formation of $\mathrm{AlPO}_{4}$ precipitates. Similarly, many studies have demonstrated that exposure to SPW worsened the protective $\mathrm{Al}(\mathrm{OH})_{3}$ coating on the nano- $\mathrm{TiO}_{2}$, thereby increasing the photocatalytic activity and toxicity of nano$\mathrm{TiO}_{2}[12,65]$. Besides changes in the surface chemistry, particles can also become more spherical and smaller when in contact with SPW [64]. This is in line with the finding that the dissolved form of Ti dominates in SPW [89], which suggests that the smaller, spherical forms represent a progressed state of $\mathrm{TiO}_{2}$ transformation. Jeon et al. [30] found that $\mathrm{TiO}_{2}$ is likely to accumulate in SPW even after a multi-stage treatment (filtration, UV irradiation, heating, and chlorination) process.

Even though more studies have examined the fate and behaviour of nano- $\mathrm{TiO}_{2}$ in natural aquatic environments compared to synthetic aqueous environments, the evaluation of synergistic interactions between multiple environmental influencing factors in both milieus is insufficient. Only a handful of researchers have studied various interacting factors in natural aquatic environments at once, and their results contradict. For example, Li et al. [101] assessed the effect of numerous natural water properties on the NP stability and found that the IS, especially $\mathrm{Ca}^{2+}$ and $\mathrm{Mg}^{2+}$, and the $\mathrm{pH}$ were the most important governing factors. In contrast, Slomberg et al. [84] observed that the nano- $\mathrm{TiO}_{2}$ stability in natural and synthetic lake water could not be compared even if the water has the same $\mathrm{pH}$ and ionic composition. This observation supports the general advice to, if possible, collect field samples instead of conducting laboratory studies as only field studies reflect the actual chemistry of the environment. In the case of Slomberg et al. [84], this refers to various combinations of NOM, suspended particulate matter (SPM), and micro-organisms that seem to have significantly affected the particle stability.

Besides the influence of NOM on the aggregation and agglomeration behaviour, $\mathrm{NOM}$ can also affect the photocatalytic behaviour of nano- $\mathrm{TiO}_{2}$ by either quenching or sensitising the generation of ROS [85]. Furthermore, a recent study has reported that nano- $\mathrm{TiO}_{2}$ can initiate the halogenation of dissolved organic matter (DOM) in fresh water and seawater, which results in the formation of organobromine and iodine compounds [93]. Previous studies have also revealed that $\mathrm{TiO}_{2}$ can increase the bioaccumulation of other environmental toxicants by effectively operating as a transport vector for heavy metals such as cadmium (Cd) or arsenic (As) [99]. Therefore, adverse effects indirectly arising from the presence of nano- $\mathrm{TiO}_{2}$ in the environment should also be considered in ecotoxicity studies.

In summary, the prediction of the behaviour and fate of nano- $\mathrm{TiO}_{2}$ based on identified predominant transport and transformation processes is still inadequate. Figure 2 schematically depicts the environmental processes that have been identified in aqueous environments. Due to the variety of interactions that occur in a single matrix, it is not yet possible to determine a distinct behaviour and fate of nano- $\mathrm{TiO}_{2}$ in one matrix, not to mention to transfer and apply the outcome to another environmental matrix. Consequently, to provide a full picture, particle and environmental characteristics should be examined 
comprehensively. However, this requires advanced analytical approaches that allow the characterisation of nano- $\mathrm{TiO}_{2}$ in complex matrices.

\section{An Analytical Challenge}

To date, existing analytical techniques have been inadequate for quantifying and disclosing the state of nano- $\mathrm{TiO}_{2}$ in diverse environmental compartments in a single analysis. Therefore, the (simultaneous) use of two or more complementary techniques is recommended as it enables the characterisation of additional particle properties and the cross-validation of results [102]. Frequently used techniques to determine the PS include (1) microscopy techniques, such as transmission electron microscopy (TEM) and scanning electron microscopy (SEM); (2) light scattering techniques, such as dynamic light scattering (DLS), multi-angle light scattering (MALS), or nanoparticle tracking analysis (NTA); (3) SPICP-MS; and (4) separation techniques, such as size exclusion chromatography (SEC), hydrodynamic chromatography (HDC), or field-flow fractionation (FFF). In their critical review, Mozhayeva et al. [103] discussed the key considerations when coupling SP-ICP-MS with separation techniques. Additionally, the review points out recent instrument and method developments that are achieved by, for example, optimising operating parameters such as plasma power and sampling position. We refer the reader to the above review for discussions concerning general SP-ICP-MS challenges.

Information about the crystalline structure of nano- $\mathrm{TiO}_{2}$ can be obtained by, for example, X-ray diffraction. Lastly, the particle mass concentration can be determined by, for example, inductively coupled plasma atomic emission spectroscopy (ICP-AES) or mass spectrometry (ICP-MS) and the number concentration by, for example, SP-ICP-MS, TEM, or SEM; the latter two are often coupled with energy dispersive x-ray spectroscopy (EDS) to confirm the chemical composition. Adam et al. [102] and Krause et al. [104] offer a detailed review of the advantages and disadvantages of various analytical techniques.

Over the past decade, SP-ICP-MS has steadily gained popularity and is currently the technique of choice as it is possible to simultaneously determine the PS and its distribution, elemental composition, and number concentration [105,106]. In particular, for NP investigations in aquatic environments, SP-ICP-MS has emerged as the leading technique as it requires minimal sample preparation compared to, for example, microscopy techniques with access to greater information. Therefore, this section focuses on (SP-)ICP-MS and provides a concise summary of the studies that attempted to detect nano- $\mathrm{TiO}_{2}$ in diverse field (Table 3) and laboratory (Table 4) aquatic environments. To the best of the authors' knowledge, this is the first review of the different approaches of sample collection, pre-treatment and (SP-)ICP-MS parameters focusing on $\mathrm{Ti}$ and nano- $\mathrm{TiO}_{2}$. 


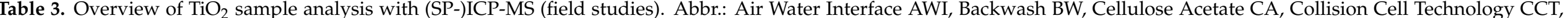

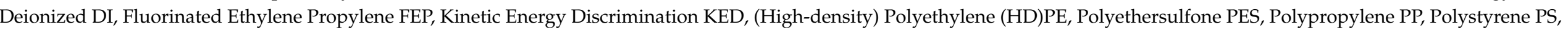

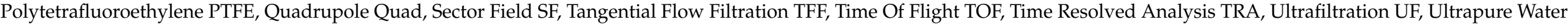
UPW, Water Surface WS.

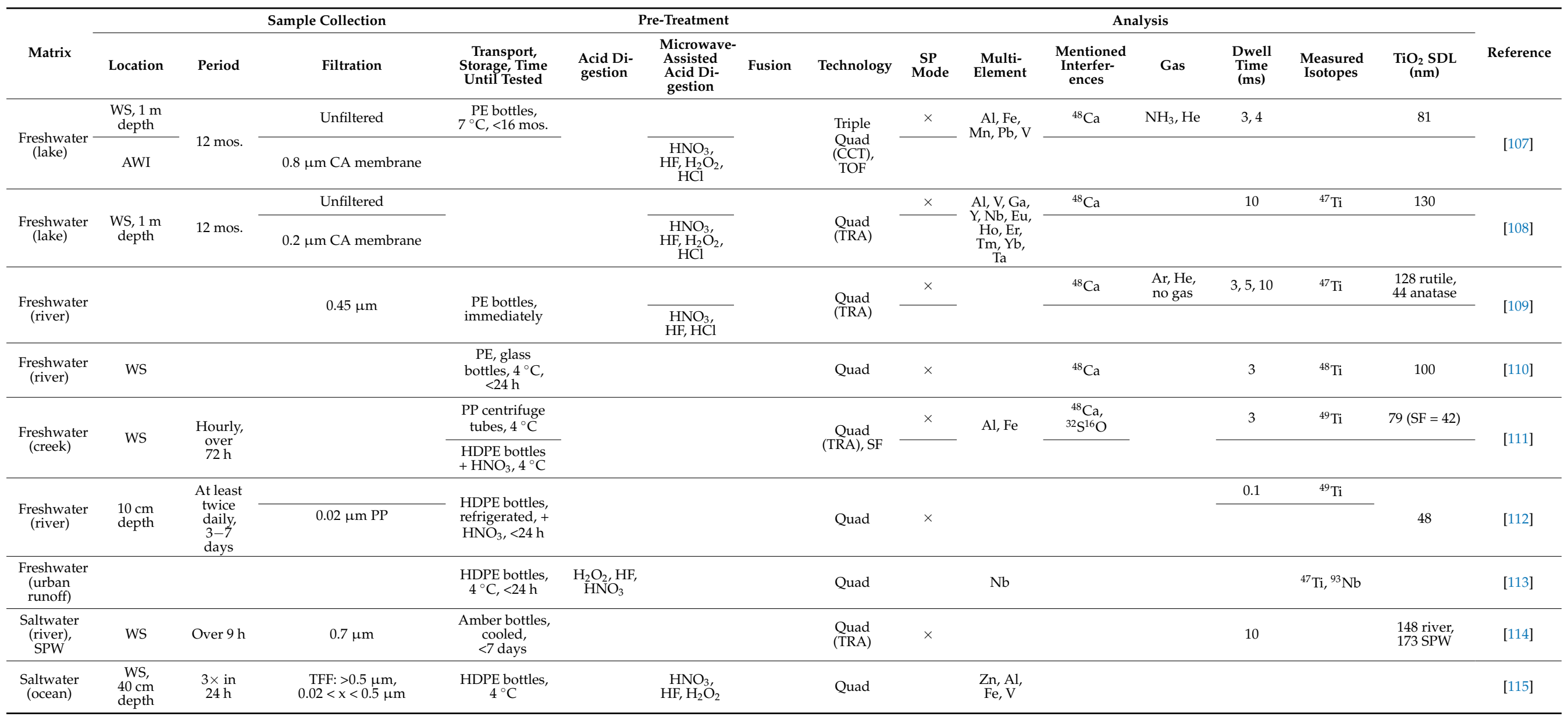


Table 3. Cont.

\begin{tabular}{|c|c|c|c|c|c|c|c|c|c|c|c|c|c|c|c|c|}
\hline \multirow[b]{2}{*}{ Matrix } & \multicolumn{4}{|c|}{ Sample Collection } & \multicolumn{3}{|c|}{ Pre-Treatment } & \multicolumn{8}{|c|}{ Analysis } & \multirow[b]{2}{*}{ Reference } \\
\hline & Location & Period & Filtration & $\begin{array}{l}\text { Transport, } \\
\text { Storage, Time } \\
\text { Until Tested }\end{array}$ & $\begin{array}{l}\text { Acid Di- } \\
\text { gestion }\end{array}$ & $\begin{array}{l}\text { Microwave- } \\
\text { Assisted } \\
\text { Acid Di- } \\
\text { gestion }\end{array}$ & Fusion & Technology & $\begin{array}{c}\text { SP } \\
\text { Mode }\end{array}$ & $\begin{array}{c}\text { Multi- } \\
\text { Element }\end{array}$ & $\begin{array}{l}\text { Mentioned } \\
\text { Interfer- } \\
\text { ences }\end{array}$ & Gas & $\begin{array}{l}\text { Dwell } \\
\text { Time } \\
\text { (ms) }\end{array}$ & $\begin{array}{l}\text { Measured } \\
\text { Isotopes }\end{array}$ & $\underset{(\mathrm{nm})}{\mathrm{TiO}_{2} \mathrm{SDL}}$ & \\
\hline $\begin{array}{l}\text { Freshwater } \\
\text { (rain), } \\
\text { SPW, } \\
\text { Milli-Q } \\
\text { water }\end{array}$ & $\begin{array}{l}30 \mathrm{~cm} \\
\text { depth } \\
(\mathrm{SPW})\end{array}$ & Once & & $\begin{array}{l}\text { FEP tubes, } \\
44^{\circ} \mathrm{C}\end{array}$ & & & & SF, Quad & $x$ & & & $\mathrm{Ar}, \mathrm{N}_{2}$ & $\begin{array}{l}0.05, \\
0.1\end{array}$ & ${ }^{49} \mathrm{Ti}$ & $\begin{array}{c}19.2 \text { wet/ } \\
12.1 \text { dry } \\
\text { aerosol, } \\
19-44 \\
\text { urban } \\
\text { waters, } \\
27 \text { SPW }\end{array}$ & [116] \\
\hline $\begin{array}{l}\text { Freshwater } \\
\text { (tap } \\
\text { water), } \\
\text { SPW, } \\
\text { sand } \\
\text { filter BW }\end{array}$ & $\begin{array}{l}5 \mathrm{~cm} \\
\text { depth } \\
(\mathrm{SPW})\end{array}$ & $\begin{array}{l}\text { Twice } \\
\text { daily, } \\
3 \text { mos. }\end{array}$ & $\begin{array}{l}\text { Spiral wound (SPW)/ } \\
\text { membrane filter } \\
\text { (BW) + TFF }\end{array}$ & $\begin{array}{l}\text { Dechlorinated, } \\
\text { PTFE bottles, } \\
\text { refrigerated, } \\
<24 \mathrm{~h}\end{array}$ & & $\mathrm{HF}$ & & $\begin{array}{l}\text { Quad } \\
\text { (CCT) }\end{array}$ & & & ${ }^{48} \mathrm{Ca}$ & $\mathrm{He}$ & $\begin{array}{l}150, \\
300\end{array}$ & ${ }^{48} \mathrm{Ti},{ }^{49} \mathrm{Ti}$ & & [89] \\
\hline SPW & & & & & & & & $\begin{array}{l}\text { Quad } \\
\text { (TRA) }\end{array}$ & $x$ & $\mathrm{Zn}, \mathrm{Al}$ & & & 0.1 & $\begin{array}{c}{ }^{47} \mathrm{Ti}^{27} \mathrm{Al}, \\
{ }^{66} \mathrm{Zn}\end{array}$ & & [117] \\
\hline \multirow{2}{*}{$\begin{array}{l}\text { Freshwater } \\
\text { (creek) } \\
\text { after } \\
\text { sewage } \\
\text { spill }\end{array}$} & & \multirow[b]{2}{*}{$\begin{array}{l}\text { Monthly, } \\
4 \text { mos. }\end{array}$} & & \multirow[b]{2}{*}{$\begin{array}{l}\text { HDPE bottles, } \\
\text { then PP tubes, } \\
4^{\circ} \mathrm{C}\end{array}$} & & & & TOF & $x$ & \multirow{2}{*}{$\begin{array}{l}\text { Various } \\
\text { (Al, V, Ga, } \\
\text { Y, Nb, Ba, } \\
\text { W, Zr, Yb, } \\
\text { Ta, Zn, Fe, } \\
\text { Mn) }\end{array}$} & & & & \multirow[b]{2}{*}{$\begin{array}{c}{ }^{47} \mathrm{Ti}^{48}{ }^{48} \mathrm{Ti} \\
{ }^{93} \mathrm{Nb}\end{array}$} & \multirow[b]{2}{*}{$\begin{array}{c}100 \\
\text { (40 UPW) }\end{array}$} & \multirow[b]{2}{*}[118]{} \\
\hline & & & & & $\begin{array}{c}\mathrm{H}_{2} \mathrm{O}_{2}, \mathrm{HF} \\
\mathrm{HNO}_{3} \\
110{ }^{\circ} \mathrm{C}\end{array}$ & & & $\mathrm{SF}$ & & & & & & & & \\
\hline \multirow{2}{*}{$\begin{array}{l}\text { Freshwater } \\
\text { (river), } \\
\text { WW } \\
\text { influent/ } \\
\text { effluent, } \\
\text { sludge }\end{array}$} & \multirow[b]{2}{*}{$\begin{array}{l}50 \mathrm{~cm} \\
\text { depth }\end{array}$} & \multirow[b]{2}{*}{ Once } & & \multirow[b]{2}{*}{$\begin{array}{l}\text { PS bottles, } 5 \\
{ }^{\circ} \mathrm{C} \text {, then PE } \\
\text { tubes }\end{array}$} & \multirow[b]{2}{*}{$\begin{array}{l}\mathrm{HNO}_{3,} \\
\mathrm{HF}, 70^{\circ} \mathrm{C} \\
\text { (overnight) }\end{array}$} & & & \multirow[b]{2}{*}{$\mathrm{SF}$} & & & & & & & & \multirow[b]{2}{*}[120]{} \\
\hline & & & $\begin{array}{ll} & \text { UF } \\
\text { Unfiltered } & 200,100 \\
+\mathrm{HNO}_{3} & 20 \mathrm{~nm})\end{array}$ & & & & & & & & & & & & & \\
\hline $\begin{array}{c}\text { WW } \\
\text { effluent }\end{array}$ & $\begin{array}{l}\text { WWTP } \\
\text { (Aus- } \\
\text { tralia) }\end{array}$ & $\begin{array}{c}24 \mathrm{~h} \\
\text { period }\end{array}$ & $\begin{array}{l}1.6 \mu \mathrm{m} \text { glass fibre }+0.45 \\
\mu \mathrm{m} \text { nylon, } 0.22 \mu \mathrm{m} \text { PES }\end{array}$ & $\begin{array}{c}4^{\circ} \mathrm{C}, \text { stored at } \\
\mathrm{pH}=2, \\
<8 \text { mos. }\end{array}$ & & & $x$ & Quad & & & & & & & & [121] \\
\hline $\begin{array}{c}\text { WW } \\
\text { influent/ } \\
\text { effluent, } \\
\text { sludge, } \\
\text { sediment }\end{array}$ & $\begin{array}{l}\text { WWTP } \\
\text { (USA) }\end{array}$ & $\begin{array}{l}\text { Monthly, } \\
12 \text { mos. }\end{array}$ & $0.2 \mu \mathrm{m}$ CA membrane & $4{ }^{\circ} \mathrm{C},<3$ days & $\begin{array}{l}\mathrm{H}_{2} \mathrm{O}_{2} \\
\mathrm{HNO}_{3}, \\
\mathrm{H}_{2} \mathrm{SO}_{4}\end{array}$ & & & & & & & & & & & [31] \\
\hline
\end{tabular}


Due to the significant variety of environmental compartments, only a few environmental matrices, such as freshwater (river, lake), have been examined more than once. Furthermore, most studies do not evaluate temporal variations. However, as shown in Tables 3 and 4, there is a consensus on collecting samples directly from the water surface, within the top 1 metre of the water column, or both. Furthermore, all samples for the total Ti concentration analysis were generally filtered using a nylon or cellulose acetate (CA) membrane with pore sizes between 0.2 and 0.8 microns. In contrast, samples for the analysis in single particle (SP) mode were seldomly filtered. Although the analysis should ideally be run shortly after the sample collection, the period between collection and analysis ranges from hours to months. The samples were mostly collected in (HD)PE containers and cooled during transport and storage.

The analysis of the total $\mathrm{Ti}$ concentration requires a pre-treatment of the sample to ensure the complete dissolution of Ti-containing particles. This is most commonly accomplished by acid digestion or microwave-assisted acid digestion using hydrofluoric $(\mathrm{HF})$ and nitric $\left(\mathrm{HNO}_{3}\right)$ acids (Tables 3 and 4$)$. Recently, alternative digestion procedures have been sought to avoid the use of highly corrosive and extremely toxic substances such as HF. For example, Mudunkotuwa et al. [122] achieved Ti recoveries of $>90 \%$ by optimising the microwave-assisted acid digestion method using concentrated sulfuric $\left(\mathrm{H}_{2} \mathrm{SO}_{4}\right)$ and $\mathrm{HNO}_{3}$ acid at a 2:1 volumetric ratio and a temperature of $210{ }^{\circ} \mathrm{C}$ holding for $45 \mathrm{~min}$. However, Markus et al. [120] subsequently established that any acid digestion of $\mathrm{TiO}_{2}$ without $\mathrm{HF}$ is incomplete and results in underestimations of the real Ti concentration. Another approach to attain the complete digestion of $\mathrm{TiO}_{2}$ to $\mathrm{Ti}^{4+}$ is fusing $\mathrm{TiO}_{2}$ with ammonium persulfate in a porcelain crucible. The fusion requires heating over an open flame (e.g., a Bunsen burner) and dissolving the reaction product in dilute $\mathrm{HNO}_{3}$ [119].

Another challenge associated with the determination of Ti using ICP-MS is the substantial polyatomic spectral interference that can originate from both native components of the environmental media such as chlorine or calcium and the oxyacids used for particle digestion such as $\mathrm{H}_{2} \mathrm{SO}_{4}$. As summarised in Tables 3 and 4, previous studies have mainly considered and attempted to prevent isobaric interferences occurring for the most abundant isotope ${ }^{48} \mathrm{Ti}(73.98 \%)$ with ${ }^{48} \mathrm{Ca}(0.19 \%)$ or ${ }^{32} \mathrm{~S}^{16} \mathrm{O}(95.04 \%)$ by measuring other stable $\mathrm{Ti}$ isotopes $[123,124]$. For example, the isotopes ${ }^{47} \mathrm{Ti}$ and ${ }^{49} \mathrm{Ti}$ with abundancies of $7.32 \%$ and $5.46 \%$ [123] were equally often considered in field studies. However, all stable Ti isotopes $\left({ }^{46-50} \mathrm{Ti}\right)$ can interfere with sulfur-based species that stem from the $\mathrm{H}_{2} \mathrm{SO}_{4}$ matrix, such as ${ }^{32} \mathrm{~S}^{14} \mathrm{~N}^{1} \mathrm{H}$ or ${ }^{32} \mathrm{~S}^{15} \mathrm{~N}$ with ${ }^{47} \mathrm{Ti}[125]$.

Table 4. Overview of $\mathrm{TiO}_{2}$ sample analysis with (SP-)ICP-MS (laboratory). Abbr:: Collision Cell Technology CCT, Deionized DI, Kinetic Energy Discrimination KED, Quadrupole Quad, Sector Field SF, Sun Lotion SL, Time Resolved Analysis TRA, Ultrapure Water UPW, Wastewater WW.

\begin{tabular}{|c|c|c|c|c|c|c|c|c|c|c|c|}
\hline \multirow[b]{2}{*}{ Matrix } & \multicolumn{2}{|c|}{ Pre-Treatment } & \multicolumn{8}{|c|}{ Analysis } & \multirow[b]{2}{*}{ Reference } \\
\hline & $\begin{array}{c}\text { Acid } \\
\text { Digestion }\end{array}$ & $\begin{array}{l}\text { Microwave- } \\
\text { Assisted Acid } \\
\text { Digestion }\end{array}$ & Technology & $\begin{array}{l}\text { SP- } \\
\text { Mode }\end{array}$ & $\begin{array}{c}\text { Multi- } \\
\text { Element }\end{array}$ & $\begin{array}{l}\text { Mentioned } \\
\text { Interfer- } \\
\text { ences }\end{array}$ & Gas & $\begin{array}{c}\text { Dwell } \\
\text { Time (ms) }\end{array}$ & $\begin{array}{l}\text { Measured } \\
\text { Isotopes }\end{array}$ & $\underset{\text { (nm) }}{\mathrm{TiO}_{2} \mathrm{SDL}}$ & \\
\hline \multirow{4}{*}{ UPW } & & & $\begin{array}{l}\text { Quad } \\
\text { (TRA) }\end{array}$ & $\times$ & & & & 0.1 & & & [126] \\
\hline & $\begin{array}{l}\mathrm{H}_{2} \mathrm{SO}_{4} \\
\mathrm{HNO}_{3}\end{array}$ & & $\begin{array}{l}\text { Quad } \\
\text { (CCT) }\end{array}$ & & & & $\begin{array}{l}\mathrm{Ar} \\
\mathrm{He}\end{array}$ & & ${ }^{46-50} \mathrm{Ti}$ & & [127] \\
\hline & & & $\begin{array}{c}\text { SF, } \\
\text { tandem } \\
\text { Quad }\end{array}$ & $\times$ & & $\begin{array}{c}{ }^{48} \mathrm{Ca} \\
{ }^{32} \mathrm{~S}^{16} \mathrm{O} \\
{ }^{36} \mathrm{Ar}^{12} \mathrm{C}\end{array}$ & $\begin{array}{c}\mathrm{O}_{2} \\
\mathrm{He} \\
+\mathrm{NH}_{3}\end{array}$ & 3,5 & $\begin{array}{c}{ }^{47-49} \mathrm{Ti}, \\
{ }^{48} \mathrm{Ca}, \\
{ }^{63} \mathrm{TiNH}\end{array}$ & $23-47$ & [128] \\
\hline & (a) $\mathrm{H}_{2} \mathrm{SO}_{4}$ & (b) $\mathrm{H}_{2} \mathrm{SO}_{4}$ & $\begin{array}{l}\text { Quad } \\
\text { (CCT) }\end{array}$ & & & & $\mathrm{He}$ & & ${ }^{47} \mathrm{Ti}$ & & [129] \\
\hline DI water & & & $\begin{array}{l}\text { Quad } \\
\text { (TRA) }\end{array}$ & $\times$ & & & $\mathrm{Ar}$ & 10 & ${ }^{47,49} \mathrm{Ti}$ & 91-95 & [130] \\
\hline \multirow{2}{*}{$\begin{array}{c}\text { SL } \\
\text { dispersed in } \\
1 \% \text { Triton } \\
\text { X-100 }\end{array}$} & & & $\begin{array}{l}\text { Quad } \\
\text { (KED) }\end{array}$ & $x$ & $\mathrm{Zn}$ & & $\mathrm{He}$ & 5 & ${ }^{48} \mathrm{Ti},{ }^{64} \mathrm{Zn}$ & 25 & [131] \\
\hline & & & Quad & $x$ & & $\begin{array}{l}{ }^{48} \mathrm{Ca}, \\
{ }^{32} \mathrm{~S}^{16} \mathrm{O}\end{array}$ & & 0.1 & ${ }^{48} \mathrm{Ti}$ & $27-29$ & [38] \\
\hline \multirow{2}{*}{$\begin{array}{l}\text { synthetic } \\
\text { WW, sludge }\end{array}$} & & $\mathrm{HCl}, \mathrm{HNO}_{3}$ & \multirow[t]{2}{*}{ Quad } & & & & \multirow[t]{2}{*}{$\mathrm{Ar}$} & & \multirow[t]{2}{*}{${ }^{48} \mathrm{Ti}$} & & \multirow[t]{2}{*}{ [132] } \\
\hline & & & & $\times$ & & & & 150 & & & \\
\hline
\end{tabular}


As shown in Tables 3 and 4, most studies were carried out using quadrupole-based ICPMS instruments. The performance of quadrupole-based systems can be improved by using the collision/reaction cell technology (CCT). This technology enables the elimination of polyatomic spectral interferences by operating in either the collision mode using inert gases and kinetic energy discrimination (KED) or the reaction mode using highly reactive gases to remove ions other than the analyte ions [133]. Other evolving technologies are the doublefocusing magnetic sector field (SF) and the time of flight (TOF) analyser technologies. When operating in SP mode, both technologies seem to reach lower PS detection limits (SDL) than the quadrupole technology due to a better mass resolution [111].

Several studies have focused on reducing the SDL of $\mathrm{TiO}_{2}$, which is relatively high due to the low mass fraction of $\mathrm{Ti}(60 \%)$ to $\mathrm{TiO}_{2}$ and the distribution of the total mass over several isotopes [128]. This may be reduced by careful consideration of the sample matrix, instrument parameters, and isotope selection. For example, Lee et al. [130] observed that low background noise and high instrument sensitivity could lower the SDL, where, for instance, the background noise can be minimised by working in the CCT mode or by using shorter dwell times. Additionally, even though the instrument sensitivity is higher for more abundant isotopes, the SDL of a less abundant isotope may still be lower due to its lower background noise, which can be derived from less isobaric interferences. The foremost effect of the background noise can also be seen when comparing the SDL of field (Table 3) and laboratory (Table 4) studies as the lower background noise in laboratory studies results in improved (i.e., smaller) SDLs.

The SP-ICP-MS analysis enables the detection and sizing of individual NPs at environmentally relevant concentrations [133] and the distinction between dissolved (ionic) and particulate forms of $\mathrm{TiO}_{2}$ [134]. In fact, SP-ICP-MS is the only technique that can detect a mixture and a wide range of PSs at environmental concentrations without preconcentration [135]. The high sensitivity and the wide dynamic range provide high size resolution, allowing the instrument to accommodate the expected polydispersity of $\mathrm{TiO}_{2}$. However, the technology may not always lead to accurate results as the method is based on several assumptions, such as spherical particle shape, which are for the most part difficult to confirm [105]. For example, the assumptions that the elemental composition is known or that the elemental components are uniformly distributed throughout the particle are problematic as particles often undergo surface treatments or particle doping. However, some assumptions can be minimised or eliminated, for instance, using the CCT technology ensures an analysis free from polyatomic interferences [105], but the high matrix complexity and variability mean that challenges remain in both laboratory and field scenarios.

There are only a few studies that have explored the prospects of using (SP-)ICP-MS as a multi-element analysis. The primary objective of those studies is to distinguish between natural (NNP) and engineered nanoparticles (ENP) based on different elemental ratios. While NNPs may contain high concentrations of, for example, vanadium (V), niobium $(\mathrm{Nb})$, aluminium $(\mathrm{Al})$, or iron $(\mathrm{Fe})$, ENPs contain none or only low amounts of these elements $[108,118]$. Even if ENPs are enclosed by Al-bearing coatings, they can be distinguished from NNPs based on the considerably higher abundance of $\mathrm{Al}$ in NNPs. Accordingly, NNPs result in lower Ti/Al ratios (0.1) compared to ENP (20-50) [108]. However, using elemental ratios to distinguish between NNPs and ENPs requires sufficiently low SDL as otherwise NNPs can be mistaken with ENPs [118]. Elemental ratios are mainly calculated based on the total metal content of a sample [113,115]. Only recently have Loosli et al. [118] and Azimzada et al. [136] succeeded in determining elemental ratios on an $\mathrm{SP}$ basis.

(SP-)ICP-MS has been shown to be capable of detecting and identifying nano- $\mathrm{TiO}_{2}$ in various matrices. However, to achieve a complete characterisation of nano- $\mathrm{TiO}_{2}$, the following challenges, which have not been sufficiently addressed, need to be examined:

- Reduction of polyatomic interferences New approaches in pre-treatments should be developed that can sufficiently digest the $\mathrm{TiO}_{2}$ sample without the use of acids that 
generate polyatomic spectral overlaps or require heavy safety measures like HF. Further developments in CCT technology could also reduce spectral interferences.

- Reduction of SDL Solely Hadioui et al. [116] have reached SDL as low as 19-44 nm for $\mathrm{TiO}_{2}$ in rainwater and $27 \mathrm{~nm}$ for $\mathrm{TiO}_{2}$ in SPW (Table 3). A low SDL is vital for detecting and accurately differentiating between small particles and the dissolved form [109,128]. If the resolution is too low, statements about the dominant form (i.e., dissolved or particulate) are not conclusive. Furthermore, adequately low SDLs are a prerequisite for effectively using (SP-)ICP-MS as a multi-element analysis [118].

- Distinction between NNPS and ENPs using multi-element analysis The advanced development of the (SP-)ICP-MS technique is required to effectively distinguish between $\mathrm{TiO}_{2}$ inputs from natural and anthropogenic sources in various matrices. A promising approach is the calculation of elemental ratios on an SP basis [118]. However, this technique is still in its infancy. Moreover, a unique fingerprint of $\mathrm{TiO}_{2}$ ENPs or NNPs should be identified to conclusively distinguish between the two [107].

- Evaluating the coating degradation using multi-element analysis The multi-element analysis could also be used to examine the potential deterioration of the particle coating. For example, Yamanaka et al. [117] have shown that $\mathrm{Al}$ and $\mathrm{Ti}$ (matrix: sunscreen), as well as Zn and Ti (matrix: SPW), can quantitatively and simultaneously be analysed using SP-ICP-MS. They verified the outcome by comparing the concentration results of the multi-element SP-ICP-MS analysis with the total metal concentration of microwavedigested samples. Future studies should investigate the suitability of this multielement analysis for observing variations in the elemental composition on an SP basis.

In summary, the use of SP-ICP-MS is increasing due to its promising research outcomes. However, the detection and the characterisation of nano- $\mathrm{TiO}_{2}$ using SP-ICP-MS is not practical in every environmental setting. Furthermore, the required measurements to determine particle behaviour and fate in each environmental media would preclude a realistic approach, both in terms of time and resource cost. Therefore, advanced modelling studies may help to address the gaps in the analytical approaches.

\section{Modelling as a Complementary Method to Analytics}

Given the existing limitations of the analytical methods for measuring nano- $\mathrm{TiO}_{2}$, modelling techniques have been employed to predict the concentrations of nano- $\mathrm{TiO}_{2}$ in the environment using material flow analysis (MFA), environmental fate modelling (EFM), or multimedia modelling. However, like analytical methods, modelling approaches (MFA, EFM) have their shortcomings, which are discussed below.

MFA models aim to estimate nano- $\mathrm{TiO}_{2}$ concentrations in the environment based on product release flows. Input data includes (1) the (global) production volume (PV); (2) the product category (PC) and its share (SPC); (3) the particle release (PR) rates often considered in a life cycle (LC) perspective (i.e., production, manufacturing, use, disposal); and (4) transfer coefficients (TC) to include mass flow within and between environmental compartments. Since MFA models depend on the accuracy of data that is scarce and mostly has a low spatial resolution, only broad estimates can be made. More advanced models treat all input parameters as probability distributions to account for data uncertainty and variability.

To further refine MFA models, a probabilistic dynamic MFA model has been developed that includes nano- $\mathrm{TiO}_{2}$ input and release dynamics [137]. Based on this model, different scenarios have been explored, such as the ban of $\mathrm{TiO}_{2}$ in cosmetics. The scenario outcome predicts a significant reduction in emission of the total nano- $\mathrm{TiO}_{2}$ in surface waters, as there is almost no delay in the release and a high percentage of the affected product type compared to the total shares [138].

Since MFA models generally do not consider transformation and only scarcely examine transport processes $[139,140]$, most modelling efforts focus on nano- $\mathrm{TiO}_{2}$ EFM, which has evolved over the past decade. EFM describes the behaviour and fate of nano- $\mathrm{TiO}_{2}$ in one or more environmental compartments. The underlying mechanisms can be, for 
example, modelled using a mechanistic approach, that is, one based on physical and biochemical principles [141,142].

Multimedia models consider the release, transport, and fate of nano- $\mathrm{TiO}_{2}$ in multiple environmental compartments, such as air, water, sediment, and soil. The objective is to give a comprehensive picture of the NP behaviour. However, most multimedia models assume that environmental compartments are well-mixed, in a steady state, or both and hence are limited in their spatial or temporal resolution or both [143]. Exceptions are the multimedia models MendNano [144] and NanoFATE [145] that both consider time-dependent effects, such as variations in particle release, seasonal weather trends, and long-term particle accumulation. However, both models are not spatially explicit. Sani-Kast et al. [146] have incorporated the spatial variability in water composition by considering different river sections, but the water chemistry within one section was assumed constant.

A literature search shows that, despite the considerable progress in model development, models have not been able to fully consider the following aspects:

- The differentiation between the form (e.g., single, aggregated, or agglomerated) of nano- $\mathrm{TiO}_{2}$ at the time of entry into the environment. A few models attempt to consider the transformation state; however, they merely manage to distinguish between pristine, dissolved, transformed (only core material), matrix-embedded, and productembedded [147] or consider only certain situations, such as an aggregated form for particles originating from WW [146].

- The impact of manufactured and natural coatings on the fate and behaviour of nano- $\mathrm{TiO}_{2}$ [148].

- Heteroaggregation/-agglomeration processes, which are not explicitly expressed as a function of environmental (e.g., $\mathrm{NOM}, \mathrm{pH}$, IS) and nano-TiO ${ }_{2}$ properties (e.g., $\mathrm{PSD}$, shape, crystallinity, coating) but rather indirectly included as part of the attachment efficiency/factor description [144,146]. Recently, the theoretical background and different experimental approaches used to study heteroaggregation have been thoroughly reviewed to at least improve the accuracy of attachment efficiency values of ENPs in natural surface waters [149].

- Environmental and nano- $\mathrm{TiO}_{2}$ properties have not been comprehensively ranked in terms of their relevancy in determining the behaviour in complex systems. Meesters et al. [150] attempted to identify the most important physicochemical properties affecting the environmental fate in their previously developed SB4N model [143]. However, available models have not yet been successful in explaining the complex systems' behaviours adequately due to an oversimplification of the modelling assumptions.

Overall, all modelling studies highlight the need for greater integration of the impact of environmental conditions on the NP's behaviour as a temporal and spatial variable [27]. They further conclude that a more comprehensive collaboration between modellers and experimentalists would improve the model's performance [27,148].

Table 5 provides an overview of recent modelling studies and summarises the considerations for model formulation. Dissolution was only listed as a transformation process if the model referred to the dissolution of the coating and not the core material. Furthermore, high spatial resolution was only acclaimed when data was not averaged over large regions such as countries or large river grids. The time variability was acknowledged as factored when, for example, time-dependent particle release or seasonal trends and not steady-state conditions were assumed.

It is known that a comprehensive RA requires information about the concentrations in the environment (exposure) and the effects (hazards) of nano- $\mathrm{TiO}_{2}$ in real-world conditions. As MFA and EFM models help to determine exposure levels, an improvement in the model formulation would concurrently lead to better results in risk forecasting. However, thus far, existing models cannot overcome and resolve the substantial data uncertainties and the insufficient understanding of the behaviours of the nano- $\mathrm{TiO}_{2}$ in realistic environments. Therefore, a model technique that can manage data limitations and is suitable for complex environmental systems needs to be introduced. 


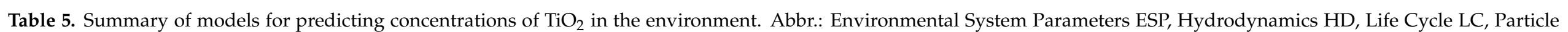

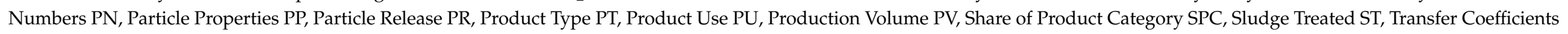
TC, Waste Incineration Plant WIP.

\begin{tabular}{|c|c|c|c|c|c|c|c|c|c|c|c|c|c|c|}
\hline \multicolumn{3}{|c|}{ Model } & \multicolumn{2}{|c|}{ Technique } & \multicolumn{7}{|c|}{ System Specification } & \multicolumn{2}{|c|}{ Fate Processes } & \multirow[b]{2}{*}{ Reference } \\
\hline MFA & EFM & Multimedia & $\begin{array}{l}\text { Probabilistic } \\
\text { Model }\end{array}$ & $\begin{array}{l}\text { Mechanistic } \\
\text { Model }\end{array}$ & $\begin{array}{l}\text { Data Type; } \\
\text { Source }\end{array}$ & $\begin{array}{c}\text { Source of } \\
\text { Nano-TiO }_{2}\end{array}$ & $\begin{array}{c}\mathrm{TiO}_{2} \\
\text { Removal, } \\
\text { Sinks }\end{array}$ & $\begin{array}{c}\text { Nanoparticle } \\
\text { Characteris- } \\
\text { tics }\end{array}$ & $\begin{array}{l}\text { Media Char- } \\
\text { acteristics }\end{array}$ & $\begin{array}{c}\text { Environmental } \\
\text { Compart- } \\
\text { ments }\end{array}$ & $\begin{array}{l}\text { Space and } \\
\text { Time Consid- } \\
\text { erations }\end{array}$ & $\begin{array}{l}\text { Transport } \\
\text { Processes }\end{array}$ & $\underset{\text { Processes }}{\text { Transformation }} \mathbf{R}$ & \\
\hline $\begin{array}{l}\text { Release } \\
\text { model; } \\
\text { distribution } \\
\text { model based } \\
\text { on [28] }\end{array}$ & & & $x$ & & $\begin{array}{l}\text { PV, SPC, PR } \\
\text { (dt), TC; } \\
\text { experiments, } \\
\text { expert } \\
\text { opinion }\end{array}$ & & $\begin{array}{l}\text { Temporal } \\
\text { (in-use } \\
\text { stock)/final } \\
\text { sinks (soil, } \\
\text { landfill, } \\
\text { sediment) }\end{array}$ & & & $\begin{array}{l}\text { Air, water, } \\
\text { soil, ST soil, } \\
\text { sediment, } \\
\text { technical } \\
\text { compart- } \\
\text { ments }\end{array}$ & $\begin{array}{l}\text { Temporally } \\
\text { resolved; } \\
\text { spatially } \\
\text { averaged (EU) }\end{array}$ & & & [137] \\
\hline $\begin{array}{l}\text { Based on } \\
\text { [28] }\end{array}$ & $\begin{array}{l}\text { Based on } \\
\text { [151] }\end{array}$ & $x$ & $x$ & & $\begin{array}{c}\text { Single input } \\
\text { source } \\
\text { (stady state): } \\
\text { STP effluent, } \\
\text { derived from } \\
\text { previous } \\
\text { MFA + PPr, } \\
\text { ESP, HD }\end{array}$ & & & $\begin{array}{l}\text { PSD, } \\
\text { Assumption: } \\
\text { Aggregated } \\
\text { form }\end{array}$ & $\begin{array}{l}\text { SPM (type, } \\
\text { conc., size), } \\
\text { constant } \\
\text { within one } \\
\text { river section }\end{array}$ & $\begin{array}{c}\text { Water, } \\
\text { sediment }\end{array}$ & $\begin{array}{c}\text { Water } \\
\text { chemistry } \\
\text { effects } \\
\text { spatially } \\
\text { resolved } \\
\text { (Rhôn River, } \\
\text { France) }\end{array}$ & $\begin{array}{l}\text { Sedimentation, } \\
\text { resuspension, } \\
\text { advection }\end{array}$ & Heteroaggregation & [146] \\
\hline \multirow[t]{4}{*}{$x$} & & & $x$ & & $\begin{array}{l}\text { PV, PC, PR } \\
\text { (LC), TC; } \\
\text { experiments, } \\
\text { assumptions }\end{array}$ & $\begin{array}{l}\text { Various (e.g., } \\
\text { cosmetics, } \\
\text { plastics, } \\
\text { paint, } \\
\text { coating) }\end{array}$ & $\begin{array}{c}\text { Soil, } \\
\text { sediment }\end{array}$ & $\begin{array}{l}\text { Distinction: } \\
\text { Anatase/rutile }\end{array}$ & & $\begin{array}{l}\text { Air, water, } \\
\text { soil, ST soil, } \\
\text { sediment, } \\
\text { technical } \\
\text { compart- } \\
\text { ments }\end{array}$ & $\begin{array}{l}\text { Spatiotemporally } \\
\text { averaged } \\
\text { (Denmark) }\end{array}$ & Sedimentation & & [140] \\
\hline & $\begin{array}{c}\times \\
\text { Simple- } \\
\text { Box4nano, } \\
\text { SB4N }\end{array}$ & $x$ & $x$ & $x$ & $\begin{array}{l}\text { PV, SPC, PR } \\
\text { (LC), PPr, } \\
\text { ESP; } \\
\text { literature, } \\
\text { models, } \\
\text { experiments, } \\
\text { DLVO } \\
\text { variables }\end{array}$ & $\begin{array}{l}\text { Various (e.g., } \\
\text { cosmetics, } \\
\text { electronics, } \\
\text { coatings, } \\
\text { paints) }\end{array}$ & $\begin{array}{l}\text { Transport } \\
\text { processes }\end{array}$ & $\begin{array}{l}\text { Physicochemical } \\
\text { properties } \\
\text { (e.g., PSD) }\end{array}$ & $\begin{array}{l}\text { E.g., PS, } \zeta \text { of } \\
\text { natural } \\
\text { particles in } \\
\text { colloidal or } \\
\text { particulate } \\
\text { form }\end{array}$ & $\begin{array}{l}\text { Air, water, } \\
\text { soil, sediment }\end{array}$ & $\begin{array}{l}\text { Spatiotemporally } \\
\text { averaged }\end{array}$ & $\begin{array}{l}\text { Sedimentation } \\
\text { (incl. burial), } \\
\text { deposition, } \\
\text { resuspension, } \\
\text { erosion, } \\
\text { advection }\end{array}$ & Heteroaggregation & [143] \\
\hline & $x$ & & & $\begin{array}{c}\text { Based on } \\
{[142]}\end{array}$ & $\begin{array}{c}\text { HD, PU, } \\
\text { input } \\
\text { scenarios: } \\
\text { WW (treated/ } \\
\text { untreated), } \\
\text { sludge } \\
\text { run-off }\end{array}$ & & WWTP & $\begin{array}{l}\text { Distinction: } \\
\text { free/unattached } \\
\text { particles, } \\
\text { homo- or het- } \\
\text { eroaggregates }\end{array}$ & SPM (conc.) & $\begin{array}{c}\text { Water, } \\
\text { sediment }\end{array}$ & $\begin{array}{l}\text { Spatiotemporally } \\
\text { averaged } \\
\text { (Rhine River, } \\
\text { Germany, } \\
\text { Netherlands) }\end{array}$ & $\begin{array}{l}\text { Sedimentation, } \\
\text { resuspension, } \\
\text { advection }\end{array}$ & $\begin{array}{l}\text { Homo- } \\
\text { /heteroaggregation }\end{array}$ & [152] \\
\hline & $\underset{\text { NanoFATE }}{\times}$ & $x$ & & & $\begin{array}{l}\text { HD, PR (dt) } \\
\text { (LC), ESP (dt) }\end{array}$ & & & $\begin{array}{c}\text { PS, } \\
\text { distinction: } \\
\text { free particles } \\
\text { or small } \\
\text { homoaggre- } \\
\text { gates, } \\
\text { heteroaggre- } \\
\text { gates }\end{array}$ & $\begin{array}{l}\text { Water } \\
\text { chemistry, } \\
\text { soil } \\
\text { properties } \\
\text { (e.g., pH) }\end{array}$ & $\begin{array}{l}\text { Air, water, } \\
\text { soil, ST soil, } \\
\text { sediment }\end{array}$ & $\begin{array}{l}\text { Temporally } \\
\text { resolved, } \\
\text { limitation: } \\
\text { spatial } \\
\text { resolution (San } \\
\text { Francisco Bay, } \\
\text { USA) }\end{array}$ & $\begin{array}{l}\text { Sedimentation } \\
\text { (incl. burial), } \\
\text { deposition, } \\
\text { resuspension, } \\
\text { soil run- } \\
\text { off/leaching, } \\
\text { advection }\end{array}$ & Heteroaggregation & [145] \\
\hline
\end{tabular}


Chen et al. [153] and Adam et al. [102] proposed the use of Bayesian networks (BN) to evaluate the risks of nano- $\mathrm{TiO}_{2}$ in the environment. This probabilistic graphical model enables multiple interconnected system variables to be incorporated and does not require experimental data or mechanistic formulations as, for example, expert elicitation can be used as a data source. However, BN has not yet been used to evaluate the interactions, effects, and risks of nano- $\mathrm{TiO}_{2}$, but it has been used as a tool

- To forecast the ecological risks of silver (Ag) NP exposure in aquatic environments (FINE model). The model integrates modules describing particle behaviour, exposure potential, hazard, and risk and was developed using expert knowledge [154].

- To predict the hazard potential and biological effects of five ENMs within the framework of a human health RA. The developed BN uses data obtained from the literature and expert elicitations and includes selected physicochemical ENM properties, human exposure routes, and biological effects [155].

- To assess environmental multimedia distributions of ENMs (BN-nanoExpo) based on simulated data derived from a previously developed multimedia fate and transport model (MendNano) [156].

Coupling different approaches such as dynamic simulation models with probabilistic modelling techniques can help to address the uncertainty in a system while capturing and examining the dynamics of a system's behaviour. Besides, data generated by one model can be used as an input for another model to improve modelling capability. This applies to spatial probabilistic modelling, in which data obtained from a geographic information system and a probabilistic model (e.g., BN, regression analysis) can be coupled to predict the spatially explicit probability of nano- $\mathrm{TiO}_{2}$ in an environmental compartment [157]. It also applies to an analytical method combined with a probabilistic modelling technique (e.g., BN), which could also improve the prediction capability and, thus, support the decision-making of whether additional actions are required.

\section{Conclusions}

In recent years, the worldwide production of $\mathrm{TiO}_{2}$ in sunscreens has increased by approximately $30 \%$ [158]. Due to this upward trend and the concerns about possible nano- $\mathrm{TiO}_{2}$ health effects, there is a need for a thorough ecological and human health RA that requires an estimate of the nano- $\mathrm{TiO}_{2}$ concentration in the environment and a better understanding of the particle behaviour as a function of particle and matrix characteristics.

In this review, relevant experimental studies examining the fate and behaviour of nano- $\mathrm{TiO}_{2}$ in sunscreen, SPW, and natural aquatic environments have been summarised. The findings show that there are three key environmental factors, namely (1) $\mathrm{pH}$ and IEP; (2) IS and ion type; and (3) type and concentration of NOM that seem to significantly govern the particle behaviour in aqueous environments. However, due to the limited ability of existing analytical techniques to determine and characterise nano- $\mathrm{TiO}_{2}$ in diverse media, the behaviour and fate of nano- $\mathrm{TiO}_{2}$ are relatively unknown.

The impacts of physicochemical particle properties (e.g., PS, shape, crystalline phase, core composition, and surface chemistry) on the fate and ecotoxicity of nano- $\mathrm{TiO}_{2}$ have also been reviewed. As the surface chemistry is one of the main determinants of the fate and ecotoxicity of nano- $\mathrm{TiO}_{2}$, the paper has especially focused on studies investigating the particle coating's durability in diverse environmental conditions and has reviewed advances in surface treatments. The results reveal that, although numerous novel coatings have been introduced in the past three years, the suitability of existing and innovative coatings in resisting harsh environmental conditions has not yet been adequately examined.

(SP-)ICP-MS is known to be one of the most promising analytical methods to detect, quantify, and characterise nano- $\mathrm{TiO}_{2}$ in environmental samples $[134,159]$. Therefore, this paper has attempted to critically examine the methodologies and results of laboratory and field (SP-)ICP-MS analysis. The results show that providing explicit and reliable test instructions to assess nano- $\mathrm{TiO}_{2}$ in different matrices is challenging due to the absence of relevant studies and the considerable variability in the experimental procedure. Con- 
sequently, more research is needed to investigate the actual behaviour of nano- $\mathrm{TiO}_{2}$ in real-world conditions instead of in controlled laboratory environments. Nevertheless, the findings of this review paper are a starting point for researchers to accelerate the process of developing new methods to identify and detect nano- $\mathrm{TiO}_{2}$ in complex media or to distinguish between ENPs and NNPs.

This review has found that even a high-resolution technique such as (SP-)ICP-MS is not adequate for the determination of NP characteristics required to measure nano$\mathrm{TiO}_{2}$ concentrations in the environment. Modelling studies (MFA, EFM) have evolved to compensate for the shortcomings of analytical techniques to estimate the concentration for RAs. The analysis of recent developments in modelling studies shows that, due to the complexity of the system and the difficulty in generalising the behaviour of various ENPs, most studies still exclude key processes such as surface transformation and lack spatial and temporal resolution. Therefore, additional modelling methods that consider interdependencies between variables and data-related uncertainties and are capable of handling a range of data from different sources are needed. In this respect, the probabilistic modelling tool $\mathrm{BN}$ has been proposed by some studies and appears to be a critical tool for future investigations.

In conclusion, relying on a standalone approach to predict nano- $\mathrm{TiO}_{2}$ concentrations in the environment is not enough, not only due to shortcomings of the individual techniques but also due to the significant variety of interactions between particles and the environment. Therefore, a new approach combining the advantages of individual techniques while eliminating their shortcomings would strengthen the prediction abilities and produce results with speed and accuracy. This would be a critical advancement that is needed to design and develop new policies.

Author Contributions: Conceptualization, S.H.; investigation, S.H.; writing—original draft preparation, S.H.; writing - review and editing, R.S., O.S. and R.A.S.; supervision, R.S., O.S. and R.A.S. All authors have read and agreed to the published version of the manuscript.

Funding: This research received no external funding.

Institutional Review Board Statement: Not applicable.

Informed Consent Statement: Not applicable.

Conflicts of Interest: The authors declare no conflict of interest.

\section{References}

1. The Skin Cancer Foundation. Skin Cancer Facts \& Statistics. 2020. Available online: https://www.skincancer.org/skin-cancerdata.information/skin-cancer-facts/ (accessed on 5 July 2019).

2. WHO. Cancer. 2018. Available online: https://www.who.int/news-room/fact-sheets/detail/cancer (accessed on 12 October 2020).

3. Tabbakh, T.; Volkov, A.; Wakefield, M.; Dobbinson, S. Implementation of the SunSmart program and population sun protection behaviour in Melbourne, Australia: Results from cross-sectional summer surveys from 1987 to 2017. PLoS Med. 2019, 16, e1002932. [CrossRef]

4. Adler, B.L.; DeLeo, V.A. Sunscreen safety: A Review of recent studies on humans and the environment. Curr. Dermatol. Rep. 2020, 9, 1-9. [CrossRef]

5. Sobek, A.; Bejgarn, S.; Rudén, C.; Molander, L.; Breitholtz, M. In the shadow of the cosmetic directive-Inconsistencies in EU environmental hazard classification requirements for UV-filters. Sci. Total. Environ. 2013, 461-462, 706-711. [CrossRef]

6. IARC. CAS No. 13463-67-7 Titanium Dioxide. 12/12/2019 ed.; International Agency for Research on Cancer: Lyon, France, 2010; Volume 93.

7. Zhang, X.; Li, W.; Yang, Z. Toxicology of nanosized titanium dioxide: An update. Arch. Toxicol. 2015, 89, 2207-2217. [CrossRef]

8. Sharma, S.; Sharma, R.K.; Gaur, K.; Torres, J.F.C.; Loza-Rosas, S.A.; Torres, A.; Saxena, M.; Julin, M.; Tinoco, A.D. Fueling a hot debate on the application of $\mathrm{TiO}_{2}$ nanoparticles in sunscreen. Materials 2019, 12, 2317. [CrossRef]

9. Fenoglio, I.; Ponti, J.; Alloa, E.; Ghiazza, M.; Corazzari, I.; Capomaccio, R.; Rembges, D.; Oliaro-Bosso, S.; Rossi, F. Singlet oxygen plays a key role in the toxicity and DNA damage caused by nanometric $\mathrm{TiO}_{2}$ in human keratinocytes. Nanoscale 2013, 5, 6567-6576. [CrossRef]

10. Mu, Q.; Jiang, G.; Chen, L.; Zhou, H.; Fourches, D.; Tropsha, A.; Yan, B. Chemical basis of interactions between engineered nanoparticles and biological systems. Chem. Rev. 2014, 114, 7740-7781. [CrossRef] [PubMed] 
11. Egambaram, O.P.; Pillai, S.K.; Ray, S.S. Materials science challenges in skin UV protection: A review. Photochem. Photobiol. 2020, 96, 779-797. [CrossRef] [PubMed]

12. Al-Abed, S.R.; Virkutyte, J.; Ortenzio, J.N.R.; McCarrick, R.M.; Degn, L.L.; Zucker, R.; Coates, N.H.; Childs, K.; Ma, H.; Diamond, S.; et al. Environmental aging alters $\mathrm{Al}(\mathrm{OH})_{3}$ coating of $\mathrm{TiO}_{2}$ nanoparticles enhancing their photocatalytic and phototoxic activities. Environ. Sci. Nano 2016, 3, 593-601. [CrossRef]

13. Auffan, M.; Pedeutour, M.; Rose, J.; Masion, A.; Ziarelli, F.; Borschneck, D.; Chanéac, C.; Botta, C.; Chaurand, P.; Labille, J.; et al. Structural degradation at the surface of $\mathrm{T} \mathrm{TiO}_{2}$-based nanomaterial used in cosmetics. Environ. Sci. Technol. 2010, 44, 2689-2694. [CrossRef] [PubMed]

14. Donia, D.T.; Carbone, M. Fate of the nanoparticles in environmental cycles. Int. J. Environ. Sci. Technol. 2018, 16, 583-600. [CrossRef]

15. Minetto, D.; Libralato, G.; Ghirardini, A.V. Ecotoxicity of engineered $\mathrm{TiO}_{2}$ nanoparticles to saltwater organisms: An overview. Environ. Int. 2014, 66, 18-27. [CrossRef] [PubMed]

16. Picado, A.; Paixão, S.M.; Moita, L.; Silva, L.; Diniz, M.S.; Lourenço, J.; Peres, I.; Castro, L.; Correia, J.B.; Pereira, J.; et al. A multi-integrated approach on toxicity effects of engineered $\mathrm{TiO}_{2}$ nanoparticles. Front. Environ. Sci. Eng. 2015, 9, 793-803. [CrossRef]

17. Scown, T.M.; Van Aerle, R.; Tyler, C.R. Review: Do engineered nanoparticles pose a significant threat to the aquatic environment? Crit. Rev. Toxicol. 2010, 40, 653-670. [CrossRef]

18. De La Vega, A.C.S.; Cruz-Alcalde, A.; Mazón, C.S.; Martí, C.B.; Diaz-Cruz, M.S. Nano-TiO 2 phototoxicity in fresh and seawater: Daphnia magna and Artemia sp. as proxies. Water 2020, 13, 55. [CrossRef]

19. Barone, A.N.; Hayes, C.E.; Kerr, J.J.; Lee, R.C.; Flaherty, D.B. Acute toxicity testing of $\mathrm{TiO}_{2}$-based vs. oxybenzone-based sunscreens on clownfish (Amphiprion ocellaris). Environ. Sci. Pollut. Res. 2019, 26, 14513-14520. [CrossRef] [PubMed]

20. Fouqueray, M.; Dufils, B.; Vollat, B.; Chaurand, P.; Botta, C.; Abacci, K.; Labille, J.; Rose, J.; Garric, J. Effects of aged TiO 2 nanomaterial from sunscreen on Daphnia magna exposed by dietary route. Environ. Pollut. 2012, 163, 55-61. [CrossRef] [PubMed]

21. Fu, L.; Hamzeh, M.; Dodard, S.; Zhao, Y.H.; Sunahara, G.I. Effects of $\mathrm{TiO}_{2}$ nanoparticles on $\mathrm{ROS}$ production and growth inhibition using freshwater green algae pre-exposed to UV irradiation. Environ. Toxicol. Pharmacol. 2015, 39, 1074-1080. [CrossRef] [PubMed]

22. ChemSafetyPro. How to Calculate Predicted No-Effect Concentration (PNEC). Available online: https: / / www.chemsafetypro. com/Topics/CRA/How_to_Calculate_Predicted_No-Effect_Concentration_(PNEC).html (accessed on 16 July 2020).

23. Musee, N. Simulated environmental risk estimation of engineered nanomaterials: A case of cosmetics in Johannesburg City. Hum. Exp. Toxicol. 2011, 30, 1181-1195. [CrossRef]

24. Coll, C.; Notter, D.; Gottschalk, F.; Sun, T.; Som, C.; Nowack, B. Probabilistic environmental risk assessment of five nanomaterials (nano- $\mathrm{TiO}_{2}$, nano-Ag, nano-ZnO, CNT, and fullerenes). Nanotoxicology 2015, 10, 436-444. [CrossRef] [PubMed]

25. Slijkerman, D.; Onderzoeksformatie, I.; Keur, M. Sunscreen Ecoproducts: Product Claims, Potential Effects and Environmental Risks of Applied UV Filters; Wageningen University and Research: Den Helder, The Netherlands, 2018.

26. Lead, J.R.; Batley, G.E.; Alvarez, P.J.J.; Croteau, M.-N.; Handy, R.D.; McLaughlin, M.J.; Judy, J.D.; Schirmer, K. Nanomaterials in the environment: Behavior, fate, bioavailability, and effects-An updated review. Environ. Toxicol. Chem. 2018, 37, $2029-2063$. [CrossRef] [PubMed]

27. Baalousha, M.; Cornelis, G.; Kuhlbusch, T.A.J.; Lynch, I.; Nickel, C.; Peijnenburg, W.; Brink, N.W.V.D. Modeling nanomaterial fate and uptake in the environment: Current knowledge and future trends. Environ. Sci. Nano 2016, 3, 323-345. [CrossRef]

28. Sun, T.Y.; Gottschalk, F.; Hungerbühler, K.; Nowack, B. Comprehensive probabilistic modelling of environmental emissions of engineered nanomaterials. Environ. Pollut. 2014, 185, 69-76. [CrossRef]

29. Number of Products, vs. Titanium Dioxide; Nanodatabase: DTU Environment, the Danish Ecological Council and Danish Consumer Council, 2020.

30. Jeon, S.-K.; Kim, E.-J.; Lee, J.; Lee, S. Potential risks of $\mathrm{TiO}_{2}$ and $\mathrm{ZnO}$ nanoparticles released from sunscreens into outdoor swimming pools. J. Hazard. Mater. 2016, 317, 312-318. [CrossRef]

31. Choi, S.; Johnston, M.; Wang, G.-S.; Huang, C. A seasonal observation on the distribution of engineered nanoparticles in municipal wastewater treatment systems exemplified by $\mathrm{TiO}_{2}$ and ZnO. Sci. Total. Environ. 2018, 625, 1321-1329. [CrossRef] [PubMed]

32. EPA, U. Nanomaterial Case Studies: Nanoscale Titanium Dioxide in Water Treatment and in Topical Sunscreen (Final); US Environmental Protection Agency Research Triangle Park: Washington, DC, USA, 2010.

33. Wiechers, J.W.; Musee, N. Engineered inorganic nanoparticles and cosmetics: Facts, issues, knowledge gaps and challenges. J. Biomed. Nanotechnol. 2010, 6, 408-431. [CrossRef]

34. Cornelis, G.; Hund-Rinke, K.; Kuhlbusch, T.; Van den Brink, N.; Nickel, C. Fate and bioavailability of engineered nanoparticles in soils: A review. Crit. Rev. Environ. Sci. Technol. 2014, 44, 2720-2764. [CrossRef]

35. Dulger, M.; Sakallioglu, T.; Temizel, I.; Demirel, B.; Copty, N.; Onay, T.; Uyguner-Demirel, C.; Karanfil, T. Leaching potential of nano-scale titanium dioxide in fresh municipal solid waste. Chemosphere 2016, 144, 1567-1572. [CrossRef] [PubMed]

36. Morgan, R.; Swimming Pool Ownership Increases in Australia. Roy Morgan Research: 2018. Available online: http://www. roymorgan.com/findings/7811-australian-swimming-pool-ownership-september-2018-201811230555 (accessed on 27 May 2020).

37. Nischwitz, V.; Goenaga-Infante, H. Improved sample preparation and quality control for the characterisation of titanium dioxide nanoparticles in sunscreens using flow field flow fractionation on-line with inductively coupled plasma mass spectrometry. $J$. Anal. At. Spectrom. 2012, 27, 1084-1092. [CrossRef] 
38. Dan, Y.; Shi, H.; Stephan, C.; Liang, X. Rapid analysis of titanium dioxide nanoparticles in sunscreens using single particle inductively coupled plasma-mass spectrometry. Microchem. J. 2015, 122, 119-126. [CrossRef]

39. Popov, A.P.; Lademann, J.; Priezzhev, A.V.; Myllylä, R.A. Effect of size of $\mathrm{TiO}_{2}$ nanoparticles embedded into stratum corneum on ultraviolet-A and ultraviolet-B sun-blocking properties of the skin. J. Biomed. Opt. 2005, 10, 064037. [CrossRef]

40. Walter, D. Primary Particles-Agglomerates-Aggregates. In Nanomaterials; Wiley: Bonn, Germany, 2013 ; pp. 9-24.

41. Lin, X.; Li, J.; Ma, S.; Liu, G.; Yang, K.; Tong, M.; Lin, D. Toxicity of $\mathrm{TiO}_{2}$ nanoparticles to escherichia coli: Effects of particle size, crystal phase and water chemistry. PLoS ONE 2014, 9, e110247. [CrossRef]

42. Solaiman, S.M.; Algie, J.; Bakand, S.; Sluyter, R.; Sencadas, V.; Lerch, M.; Huang, X.-F.; Konstantinov, K.; Barker, P.J. Nanosunscreens-A double-edged sword in protecting consumers from harm: Viewing Australian regulatory policies through the lenses of the European Union. Crit. Rev. Toxicol. 2019, 49, 122-139. [CrossRef]

43. Pelclova, D.; Navratil, T.; Kacerova, T.; Zamostna, B.; Fenclova, Z.; Vlckova, S.; Kacer, P. NanoTiO ${ }_{2}$ sunscreen does not prevent systemic oxidative stress caused by UV radiation and a minor amount of $\mathrm{NanoTiO}_{2}$ is absorbed in humans. Nanomater. 2019, 9, 888. [CrossRef]

44. Almquist, C.B.; Biswas, P. Role of synthesis method and particle size of nanostructured $\mathrm{TiO}_{2}$ on its photoactivity. J. Catal. 2002, 212, 145-156. [CrossRef]

45. Philippe, A.; Košík, J.; Welle, A.; Guigner, J.-M.; Clemens, O.; Schaumann, G.E. Extraction and characterization methods for titanium dioxide nanoparticles from commercialized sunscreens. Environ. Sci. Nano 2017, 5, 191-202. [CrossRef]

46. Bairi, V.G.; Lim, J.-H.; Fong, A.; Linder, S.W. Size characterization of metal oxide nanoparticles in commercial sunscreen products. J. Nanoparticle Res. 2017, 19, 256. [CrossRef]

47. Robertson, T.A.; Sanchez, W.Y.; Roberts, M.S. Are commercially available nanoparticles safe when applied to the skin? J. Biomed. Nanotechnol. 2010, 6, 452-468. [CrossRef] [PubMed]

48. Catalano, R.; Labille, J.; Gaglio, D.; Alijagic, A.; Napodano, E.; Slomberg, D.; Campos, A.; Pinsino, A. Safety evaluation of TiO 2 nanoparticle-based sunscreen UV filters on the development and the immunological state of the sea urchin Paracentrotus Lividus. Nanomaterials 2020, 10, 2102. [CrossRef] [PubMed]

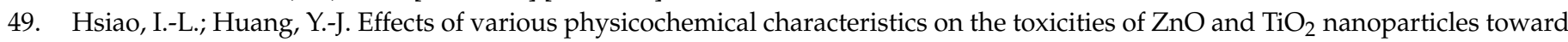
human lung epithelial cells. Sci. Total. Environ. 2011, 409, 1219-1228. [CrossRef]

50. Lu, P.; Fang, S.; Cheng, W.; Huang, S.; Cheng, H. Characterization of titanium dioxide and zinc oxide nanoparticles in sunscreen powder by comparing different measurement methods. J. Food Drug Anal. 2018, 26, 1192-1200. [CrossRef] [PubMed]

51. He, X.; Hwang, H.-M. Engineered TiO ${ }_{2}$ Nanoparticles: Their Fate and Effects in Natural Aquatic Environments; Nova Science Publishers Inc.: Jackson, MS, USA, 2014; pp. 1-20.

52. Johnston, H.J.; Hutchison, G.R.; Christensen, F.M.; Peters, S.; Hankin, S.; Stone, V. Identification of the mechanisms that drive the toxicity of $\mathrm{TiO}_{2}$ particulates: The contribution of physicochemical characteristics. Part. Fibre Toxicol. 2009, 6, 33. [CrossRef]

53. Corinaldesi, C.; Marcellini, F.; Nepote, E.; Damiani, E.; Danovaro, R. Impact of inorganic UV filters contained in sunscreen products on tropical stony corals (Acropora spp.). Sci. Total Environ. 2018, 637-638, 1279-1285. [CrossRef] [PubMed]

54. Borm, P.J.; Robbins, D.; Haubold, S.; Kuhlbusch, T.; Fissan, H.; Donaldson, K.; Schins, R.; Stone, V.; Kreyling, W.; Lademann, J.; et al. The potential risks of nanomaterials: A review carried out for ECETOC. Part. Fibre Toxicol. 2006, 3, 11. [CrossRef]

55. Wakefield, G.; Lipscomb, S.; Holland, E.; Knowland, J. The effects of manganese doping on UVA absorption and free radical generation of micronised titanium dioxide and its consequences for the photostability of UVA absorbing organic sunscreen components. Photochem. Photobiol. Sci. 2004, 3, 648-652. [CrossRef]

56. Park, B.; Martin, A.P.; Harris, C.; Guest, R.; Whittingham, A.; Jenkinson, P. Preliminary in vitro investigation of the potential health effects of Optisol ${ }^{\mathrm{TM}}$, a nanoparticulate manganese modified titanium dioxide UV-filter used in certain sunscreen products. Nanotoxicology 2009, 3, 73-90. [CrossRef]

57. Labille, J.; Catalano, R.; Slomberg, D.; Motellier, S.; Pinsino, A.; Hennebert, P.; Santaella, C.; Bartolomei, V. Assessing sunscreen lifecycle to minimize environmental risk posed by nanoparticulate UV-filters-A review for safer-by-design products. Front. Environ. Sci. 2020, 8. [CrossRef]

58. Jacobs, J.F.; Van De Poel, I.; Osseweijer, P. Sunscreens with titanium dioxide $\left(\mathrm{TiO}_{2}\right)$ nano-particles: A societal experiment. NanoEthics 2010, 4, 103-113. [CrossRef]

59. Osterwalder, U.; Sohn, M.; Herzog, B. Global state of sunscreens. Photodermatol. Photoimmunol. Photomed. 2014, 30, 62-80. [CrossRef]

60. Rossano, M.; Hucher, N.; Picard, C.; Colletta, D.; Le Foll, F.; Grisel, M. Effects of aging on structure and stability of TiO 2 nanoparticle-containing oil-in-water emulsions. Int. J. Pharm. 2014, 461, 89-96. [CrossRef]

61. Dréno, B.; Alexis, A.; Chuberre, B.; Marinovich, M. Safety of titanium dioxide nanoparticles in cosmetics. J. Eur. Acad. Dermatol. Venereol. 2019, 33, 34-46. [CrossRef]

62. Wu, W.; Xiang, Q.; Wu, Z.; Shan, G.; Zhu, L. Depletion of double-layer coated nano-TiO ${ }_{2}$ and generation of reactive oxygen species in the presence of ethanol under simulated solar irradiation. NanoImpact 2018, 11, 164-169. [CrossRef]

63. Labille, J.; Feng, J.; Botta, C.; Borschneck, D.; Sammut, M.; Cabie, M.; Auffan, M.; Rose, J.; Bottero, J.-Y. Aging of TiO 2 nanocomposites used in sunscreen. Dispersion and fate of the degradation products in aqueous environment. Environ. Pollut. 2010, 158, 3482-3489. [CrossRef] 
64. Virkutyte, J.; Al-Abed, S.R. Statistical evaluation of potential damage to the $\mathrm{Al}(\mathrm{OH})_{3}$ layer on $\mathrm{nTiO} \mathrm{O}_{2}$ particles in the presence of swimming pool and seawater. J. Nanoparticle Res. 2012, 14, 787. [CrossRef]

65. Virkutyte, J.; Al-Abed, S.R.; Dionysiou, D.D. Depletion of the protective aluminum hydroxide coating in $\mathrm{TiO}_{2}$-based sunscreens by swimming pool water ingredients. Chem. Eng. J. 2012, 191, 95-103. [CrossRef]

66. Wallis, L.K.; Diamond, S.A.; Ma, H.; Hoff, D.J.; Al-Abed, S.R.; Li, S. Chronic $\mathrm{TiO}_{2}$ nanoparticle exposure to a benthic organism, Hyalella azteca: Impact of solar UV radiation and material surface coatings on toxicity. Sci. Total. Environ. 2014, 499, 356-362. [CrossRef] [PubMed]

67. Morsella, M.; D'Alessandro, N.; Lanterna, A.E.; Scaiano, J.C. Improving the sunscreen properties of $\mathrm{TiO}_{2}$ through an understanding of its catalytic properties. ACS Omega 2016, 1, 464-469. [CrossRef] [PubMed]

68. Yu, J.; Li, L.; Qian, Y.; Lou, H.; Yang, D.; Qiu, X. Facile and green preparation of high UV-blocking lignin/titanium dioxide nanocomposites for developing natural sunscreens. Ind. Eng. Chem. Res. 2018, 57, 15740-15748. [CrossRef]

69. Shandilya, N.; Capron, I. Safer-by-design hybrid nanostructures: An alternative to conventional titanium dioxide UV filters in skin care products. RSC Adv. 2017, 7, 20430-20439. [CrossRef]

70. Son, H.Y.; Koo, B.I.; Lee, J.B.; Kim, K.R.; Kim, W.; Jang, J.; Yoon, M.S.; Cho, J.-W.; Nam, Y.S. Tannin-titanium oxide multilayer as a photochemically suppressed ultraviolet filter. ACS Appl. Mater. Interfaces 2018, 10, 27344-27354. [CrossRef]

71. Battistin, M.; Dissette, V.; Bonetto, A.; Durini, E.; Manfredini, S.; Marcomini, A.; Casagrande, E.; Brunetta, A.; Ziosi, P.; Molesini, S.; et al. A new approach to UV protection by direct surface functionalization of $\mathrm{TiO}_{2}$ with the antioxidant polyphenol dihydroxyphenyl benzimidazole carboxylic acid. Nanomater. 2020, 10, 231. [CrossRef] [PubMed]

72. Åhlén, M.; Cheung, O.; Strømme, M. Amorphous mesoporous magnesium carbonate as a functional support for UV-blocking semiconductor nanoparticles for cosmetic applications. ACS Omega 2019, 4, 4429-4436. [CrossRef]

73. Bernstein, E.F.; Sarkas, H.W.; Ba, P.B.; Bouche, D. Beyond sun protection factor: An approach to environmental protection with novel mineral coatings in a vehicle containing a blend of skincare ingredients. J. Cosmet. Dermatol. 2020, 19, 407-415. [CrossRef]

74. Borrás, M.C.; Sluyter, R.; Barker, P.J.; Konstantinov, K.; Bakand, S. $\mathrm{Y}_{2} \mathrm{O}_{3}$ decorated $\mathrm{TiO}_{2}$ nanoparticles: Enhanced UV attenuation and suppressed photocatalytic activity with promise for cosmetic and sunscreen applications. J. Photochem. Photobiol. B: Biol. 2020, 207, 111883. [CrossRef]

75. Morlando, A.; Borrás, M.C.; Rehman, Y.; Bakand, S.; Barker, P.; Sluyter, R.; Konstantinov, K. Development of CeO 2 nanodot encrusted $\mathrm{TiO}_{2}$ nanoparticles with reduced photocatalytic activity and increased biocompatibility towards a human keratinocyte cell line. J. Mater. Chem. B 2020, 8, 4016-4028. [CrossRef] [PubMed]

76. Derjaguin, B.; Landau, L. Theory of the stability of strongly charged lyophobic sols and of the adhesion of strongly charged particles in solutions of electrolytes. Prog. Surf. Sci. 1993, 43, 30-59. [CrossRef]

77. Overbeek, T.; Verwey, E. Theory of the Stability of Lyophobic Colloids: The Interaction of Sol Particles Having An Electric Double Layer; Elsevier: Amsterdam, The Netherlands, 1948.

78. Beck, R.; Guterres, S.; Pohlmann, A. Nanocosmetics and Nanomedicines; Springer: Berlin/Heidelberg, Germany, 2011. [CrossRef]

79. Stumm, W.; Morgan, J.J.; ProQuest, E. Aquatic Chemistry: Chemical Equilibria and Rates in Natural Waters, 3rd ed.; Wiley: New York, NY, USA, 1996.

80. Nobbmann, U. Nanomaterial Isoelectric Points IEPs; Malvern Panalytical Ltd: Malvern, UK, 2017.

81. Englehart, J.; Lyon, B.A.; Abriola, L.M.; Becker, M.D.; Wang, Y.; Pennell, K.D. Influence of a polymer sunscreen additive on the transport and retention of titanium dioxide nanoparticles in water-saturated porous media. Environ. Sci. Nano 2015, 3, 157-168. [CrossRef]

82. Zhang, C.; Lohwacharin, J.; Takizawa, S. Properties of residual titanium dioxide nanoparticles after extended periods of mixing and settling in synthetic and natural waters. Sci. Rep. 2017, 7, 9943. [CrossRef]

83. Luo, M.; Huang, Y.; Zhu, M.; Tang, Y.-N.; Ren, T.; Ren, J.; Wang, H.; Li, F. Properties of different natural organic matter influence the adsorption and aggregation behavior of $\mathrm{TiO}_{2}$ nanoparticles. J. Saudi Chem. Soc. 2018, 22, 146-154. [CrossRef]

84. Slomberg, D.L.; Ollivier, P.; Miche, H.; Angeletti, B.; Bruchet, A.; Philibert, M.; Brant, J.; Labille, J. Nanoparticle stability in lake water shaped by natural organic matter properties and presence of particulate matter. Sci. Total. Environ. 2019, 656, 338-346. [CrossRef]

85. Li, S.; Ma, H.; Wallis, L.K.; Etterson, M.A.; Riley, B.; Hoff, D.J.; Diamond, S.A. Impact of natural organic matter on particle behavior and phototoxicity of titanium dioxide nanoparticles. Sci. Total. Environ. 2016, 542, 324-333. [CrossRef]

86. Labille, J.; Harns, C.; Bottero, J.-Y.; Brant, J. Heteroaggregation of titanium dioxide nanoparticles with natural clay colloids. Environ. Sci. Technol. 2015, 49, 6608-6616. [CrossRef]

87. De La Vega, A.C.S.; Molins-Delgado, D.; Barceló, D.; Díaz-Cruz, M.S. Nanosized titanium dioxide UV filter increases mixture toxicity when combined with parabens. Ecotoxicol. Environ. Saf. 2019, 184, 109565. [CrossRef] [PubMed]

88. Kim, E.; Kim, M.; Im, N.; Park, S. Photolysis of the organic UV filter, avobenzone, combined with octyl methoxycinnamate by nano-TiO 2 composites. J. Photochem. Photobiol. B: Biol. 2015, 149, 196-203. [CrossRef]

89. Holbrook, R.D.; Motabar, D.; Quiñones, O.; Stanford, B.; Vanderford, B.; Moss, D. Titanium distribution in swimming pool water is dominated by dissolved species. Environ. Pollut. 2013, 181, 68-74. [CrossRef] [PubMed]

90. Sánchez-Quiles, D.; Tovar-Sánchez, A. Sunscreens as a source of hydrogen peroxide production in coastal waters. Environ. Sci. Technol. 2014, 48, 9037-9042. [CrossRef] [PubMed] 
91. Zhou, D.; Bennett, S.W.; Keller, A.A. Increased mobility of metal oxide nanoparticles due to photo and thermal induced disagglomeration. PLoS ONE 2012, 7, e37363. [CrossRef]

92. Lv, X.; Tao, J.; Chen, B.; Zhu, X. Roles of temperature and flow velocity on the mobility of nano-sized titanium dioxide in natural waters. Sci. Total. Environ. 2016, 565, 849-856. [CrossRef] [PubMed]

93. Hao, Z.; Yin, Y.; Wang, J.; Cao, D.; Liu, J. Formation of organobromine and organoiodine compounds by engineered $\mathrm{TiO}_{2}$ nanoparticle-induced photohalogenation of dissolved organic matter in environmental waters. Sci. Total. Environ. 2018, 631-632, 158-168. [CrossRef]

94. Loosli, F.; Le Coustumer, P.; Stoll, S. $\mathrm{TiO}_{2}$ nanoparticles aggregation and disaggregation in presence of alginate and Suwannee River humic acids. $\mathrm{pH}$ and concentration effects on nanoparticle stability. Water Res. 2013, 47, 6052-6063. [CrossRef] [PubMed]

95. Sendra, M.; Yeste, M.; Gatica, J.; Moreno-Garrido, I.; Blasco, J. Homoagglomeration and heteroagglomeration of $\mathrm{TiO}_{2}$, in nanoparticle and bulk form, onto freshwater and marine microalgae. Sci. Total. Environ. 2017, 592, 403-411. [CrossRef] [PubMed]

96. Botta, C.; Labille, J.; Auffan, M.; Borschneck, D.; Miche, H.; Cabié, M.; Masion, A.; Rose, J.; Bottero, J.-Y. TiO 2 -based nanoparticles released in water from commercialized sunscreens in a life-cycle perspective: Structures and quantities. Environ. Pollut. 2011, 159, 1543-1550. [CrossRef] [PubMed]

97. Rodríguez-Romero, A.; Ruiz-Gutiérrez, G.; Viguri, J.R.; Tovar-Sánchez, A. Sunscreens as a new source of metals and nutrients to coastal waters. Environ. Sci. Technol. 2019, 53, 10177-10187. [CrossRef] [PubMed]

98. Fan, W.; Cui, M.; Liu, H.; Wang, C.; Shi, Z.; Tan, C.; Yang, X. Nano-TiO 2 enhances the toxicity of copper in natural water to daphnia magna. Environ. Pollut. 2011, 159, 729-734. [CrossRef]

99. Skocaj, M.; Filipic, M.; Petkovic, J.; Novak, S. Titanium dioxide in our everyday life; is it safe? Radiol. Oncol. 2011, 45, 227-247. [CrossRef]

100. Santaella, C.; Allainmat, B.; Simonet, F.; Chanéac, C.; Labille, J.; Auffan, M.; Rose, J.; Achouak, W. Aged TiÖ2-based nanocomposite used in sunscreens produces singlet oxygen under long-wave UV and sensitizesescherichia colito cadmium. Environ. Sci. Technol. 2014, 48, 5245-5253. [CrossRef]

101. Li, L.; Sillanpää, M.; Risto, M. Influences of water properties on the aggregation and deposition of engineered titanium dioxide nanoparticles in natural waters. Environ. Pollut. 2016, 219, 132-138. [CrossRef]

102. Adam, V.; Loyaux-Lawniczak, S.; Quaranta, G. Characterization of engineered $\mathrm{TiO}_{2}$ nanomaterials in a life cycle and risk assessments perspective. Environ. Sci. Pollut. Res. 2015, 22, 11175-11192. [CrossRef]

103. Mozhayeva, D.; Engelhard, C. A critical review of single particle inductively coupled plasma mass spectrometry-A step towards an ideal method for nanomaterial characterization. J. Anal. At. Spectrom. 2019, 35, 1740-1783. [CrossRef]

104. Krause, B.; Meyer, T.; Sieg, H.; Kästner, C.; Reichardt, P.; Tentschert, J.; Jungnickel, H.; Estrela-Lopis, I.; Burel, A.; Chevance, S.; et al. Characterization of aluminum, aluminum oxide and titanium dioxide nanomaterials using a combination of methods for particle surface and size analysis. RSC Adv. 2018, 8, 14377-14388. [CrossRef]

105. Wilbur, S.; Yamanaka, M.; Sannac, S. Characterization of Nanoparticles in Aqueous Samples by ICP-MS.; Agilent Technologies, Inc.: Santa Clara, CA, USA, 2017.

106. Bustos, A.R.M.; Winchester, M.R. Single-particle-ICP-MS advances. Anal. Bioanal. Chem. 2016, 408, 5051-5052. [CrossRef]

107. Gondikas, A.; Von Der Kammer, F.; Kaegi, R.; Borovinskaya, O.; Neubauer, E.; Navratilova, J.; Praetorius, A.; Cornelis, G.; Hofmann, T. Where is the nano? Analytical approaches for the detection and quantification of $\mathrm{TiO}_{2}$ engineered nanoparticles in surface waters. Environ. Sci. Nano 2017, 5, 313-326. [CrossRef]

108. Gondikas, A.P.; Von Der Kammer, F.; Reed, R.B.; Wagner, S.; Ranville, J.F.; Hofmann, T. Release of TiO 2 nanoparticles from sunscreens into surface waters: A one-year survey at the old danube recreational lake. Environ. Sci. Technol. 2014, 48, 5415-5422. [CrossRef]

109. Vidmar, J.; Milačič, R.; Ščančar, J. Sizing and simultaneous quantification of nanoscale titanium dioxide and a dissolved titanium form by single particle inductively coupled plasma mass spectrometry. Microchem. J. 2017, 132, 391-400. [CrossRef]

110. Peters, R.J.; van Bemmel, G.; Milani, N.B.; Hertog, G.C.D.; Undas, A.K.; van der Lee, M.; Bouwmeester, H. Detection of nanoparticles in Dutch surface waters. Sci. Total. Environ. 2018, 621, 210-218. [CrossRef]

111. Reed, R.B.; Martin, D.P.; Bednar, A.J.; Montaño, M.D.; Westerhoff, P.; Ranville, J.F. Multi-day diurnal measurements of Ticontaining nanoparticle and organic sunscreen chemical release during recreational use of a natural surface water. Environ. Sci. Nano 2017, 4, 69-77. [CrossRef]

112. Rand, L.N.; Bi, Y.; Poustie, A.; Bednar, A.J.; Hanigan, D.J.; Westerhoff, P.; Ranville, J.F. Quantifying temporal and geographic variation in sunscreen and mineralogic titanium-containing nanoparticles in three recreational rivers. Sci. Total. Environ. 2020, 743, 140845. [CrossRef]

113. Wang, J.; Nabi, M.; Mohanty, S.K.; Afrooz, A.N.; Cantando, E.; Aich, N.; Baalousha, M. Detection and quantification of engineered particles in urban runoff. Chemosphere 2020, 248, 126070. [CrossRef] [PubMed]

114. Venkatesan, A.K.; Reed, R.B.; Lee, S.; Bi, X.; Hanigan, D.; Yang, Y.; Ranville, J.F.; Herckes, P.; Westerhoff, P. Detection and sizing of Ti-containing particles in recreational waters using single particle ICP-MS. Bull. Environ. Contam. Toxicol. 2018, 100, 120-126. [CrossRef] [PubMed]

115. Labille, J.; Slomberg, D.; Catalano, R.; Robert, S.; Apers-Tremelo, M.-L.; Boudenne, J.-L.; Manasfi, T.; Radakovitch, O. Assessing UV filter inputs into beach waters during recreational activity: A field study of three French Mediterranean beaches from consumer survey to water analysis. Sci. Total. Environ. 2020, 706, 136010. [CrossRef] [PubMed] 
116. Hadioui, M.; Knapp, G.; Azimzada, A.; Jreije, I.; Frechette-Viens, L.; Wilkinson, K.J. Lowering the Size Detection Limits of Ag and $\mathrm{TiO}_{2}$ Nanoparticles by Single Particle ICP-MS. Anal. Chem. 2019, 91, 13275-13284. [CrossRef] [PubMed]

117. Yamanaka, M.; Itagaki, T.; Wilbur, S. Measuring Multiple Elements in Nanoparticles Using spICP-MS; Agilent Technologies, Inc.: Santa Clara, CA, USA, 2018.

118. Loosli, F.; Wang, J.; Rothenberg, S.; Bizimis, M.; Winkler, C.; Borovinskaya, O.; Flamigni, L.; Baalousha, M. Sewage spills are a major source of titanium dioxide engineered (nano)-particle release into the environment. Environ. Sci. Nano 2019, 6, 763-777. [CrossRef]

119. Khosravi, K.; Hoque, M.E.; Dimock, B.; Hintelmann, H.; Metcalfe, C.D. A novel approach for determining total titanium from titanium dioxide nanoparticles suspended in water and biosolids by digestion with ammonium persulfate. Anal. Chim. Acta 2012, 713, 86-91. [CrossRef]

120. Markus, A.; Krystek, P.; Tromp, P.; Parsons, J.; Roex, E.; De Voogt, P.; Laane, R. Determination of metal-based nanoparticles in the river Dommel in the Netherlands via ultrafiltration, HR-ICP-MS and SEM. Sci. Total. Environ. 2018, 631-632, 485-495. [CrossRef]

121. Neale, P.A.; Jämting, Å.K.; O'Malley, E.; Herrmann, J.; Escher, B.I. Behaviour of titanium dioxide and zinc oxide nanoparticles in the presence of wastewater-derived organic matter and implications for algal toxicity. Environ. Sci. Nano 2015, 2, 86-93. [CrossRef]

122. Mudunkotuwa, I.A.; Anthony, T.R.; Grassian, V.H.; Peters, T.M. Accurate quantification of $\mathrm{TiO}_{2}$ nanoparticles collected on air filters using a microwave-assisted acid digestion method. J. Occup. Environ. Hyg. 2016, 13, 30-39. [CrossRef]

123. May, T.W.; Wiedmeyer, R.H. A table of polyatomic interferences in ICP-MS. At. Spectrosc. Norwalk Conn. 1998, $19,150-155$.

124. Raeve, P.; Bianga, J. Fast and Accurate Absolute-Quantification of Proteins and Antibodies Using Isotope Dilution-Triple Quadrupole ICP-MS; Agilent Technologies, Inc.: Santa Clara, CA, USA, 2015.

125. Wills, J.D.; Lindemann, T. Analysis of Sulfuric Acid Using a Single Set of Operating Conditions with HR-ICP-MS.; Thermo Fisher Scientific Inc.: Waltham, MA, USA, 2016.

126. Yamanaka, M.; Yamanaka, K.; Itagaki, T.; Wilbur, S.; McCurdy, E. Automated, High Sensitivity Analysis of Single Nanoparticles Using the Agilent 7900 ICP-MS with Single Nanoparticle Application Module; Agilent Technologies, Inc.: Santa Clara, CA, USA, 2015.

127. Watkins, P.S.; Castellon, B.T.; Tseng, C.; Wright, M.V.; Matson, C.W.; Cobb, G.P. Validation of a sulfuric acid digestion method for inductively coupled plasma mass spectrometry quantification of $\mathrm{TiO}_{2}$ nanoparticles. Bull. Environ. Contam. Toxicol. 2018, 100, 809-814. [CrossRef] [PubMed]

128. Tharaud, M.; Gondikas, A.P.; Benedetti, M.F.; Von Der Kammer, F.; Hofmann, T.; Cornelis, G. TiO 2 nanomaterial detection in calcium rich matrices by spICPMS. A matter of resolution and treatment. J. Anal. At. Spectrom. 2017, 32, 1400-1411. [CrossRef]

129. Fabricius, A.-L.; Duester, L.; Meermann, B.; Ternes, T.A. ICP-MS-based characterization of inorganic nanoparticles-Sample preparation and off-line fractionation strategies. Anal. Bioanal. Chem. 2014, 406, 467-479. [CrossRef] [PubMed]

130. Lee, S.; Bi, X.; Reed, R.B.; Ranville, J.F.; Herckes, P.; Westerhoff, P. Nanoparticle size detection limits by single particle ICP-MS for 40 elements. Environ. Sci. Technol. 2014, 48, 10291-10300. [CrossRef] [PubMed]

131. Bocca, B.; Caimi, S.; Senofonte, O.; Alimonti, A.; Petrucci, F. ICP-MS based methods to characterize nanoparticles of TiO 2 and $\mathrm{ZnO}$ in sunscreens with focus on regulatory and safety issues. Sci. Total. Environ. 2018, 630, 922-930. [CrossRef]

132. Lange, T.; Schneider, P.; Schymura, S.; Franke, K. The fate of anthropogenic nanoparticles, $\mathrm{nTiO}_{2}$ and $\mathrm{nCeO}_{2}$, in waste water treatment. Water 2020, 12, 2509. [CrossRef]

133. Thomas, R. Practical Guide to ICP-MS: A Tutorial for Beginners; CRC Press LLC: Baton Rouge, LA, USA, 2013.

134. Laborda, F.; Bolea, E.; Jiménez-Lamana, J. Single particle inductively coupled plasma mass spectrometry: A powerful tool for nanoanalysis. Anal. Chem. 2014, 86, 2270-2278. [CrossRef]

135. Merrifield, R.C.; Stephan, C.; Lead, J.R. Single-particle inductively coupled plasma mass spectroscopy analysis of size and number concentration in mixtures of monometallic and bimetallic (core-shell) nanoparticles. Talanta 2017, 162, 130-134. [CrossRef] [PubMed]

136. Azimzada, A.; Farner, J.M.; Jreije, I.; Hadioui, M.; Liu-Kang, C.; Tufenkji, N.; Shaw, P.; Wilkinson, K.J. Single- and multi-element quantification and characterization of $\mathrm{TiO}_{2}$ nanoparticles released from outdoor stains and paints. Front. Environ. Sci. 2020, 8. [CrossRef]

137. Sun, T.Y.; Bornhöft, N.A.; Hungerbuehler, K.; Nowack, B. Dynamic Probabilistic Modeling of environmental emissions of engineered nanomaterials. Environ. Sci. Technol. 2016, 50, 4701-4711. [CrossRef] [PubMed]

138. Sun, T.Y.; Mitrano, D.M.; Bornhöft, N.A.; Scheringer, M.; Hungerbühler, K.; Nowack, B. Envisioning nano release dynamics in a changing world: Using dynamic probabilistic modeling to assess future environmental emissions of engineered nanomaterials Environ. Sci. Technol. 2017, 51, 2854-2863. [CrossRef] [PubMed]

139. Gottschalk, F.; Sonderer, T.; Scholz, R.W.; Nowack, B. Modeled Environmental concentrations of engineered nanomaterials (TiO ${ }_{2}$, $\mathrm{ZnO}, \mathrm{Ag}, \mathrm{CNT}$, fullerenes) for different regions. Environ. Sci. Technol. 2009, 43, 9216-9222. [CrossRef]

140. Gottschalk, F.; Lassen, C.; Kjoelholt, J.; Christensen, F.; Nowack, B. Modeling flows and concentrations of nine engineered nanomaterials in the danish environment. Int. J. Environ. Res. Public Health 2015, 12, 5581-5602. [CrossRef]

141. Meesters, J.A.J.; Koelmans, A.A.; Quik, J.T.K.; Hendriks, A.J.; Van De Meent, D. Multimedia modeling of engineered nanoparticles with SimpleBox4nano: Model definition and evaluation. Environ. Sci. Technol. 2014, 48, 5726-5736. [CrossRef] [PubMed]

142. Markus, A.; Parsons, J.; Roex, E.; De Voogt, P.; Laane, R. Modeling aggregation and sedimentation of nanoparticles in the aquatic environment. Sci. Total. Environ. 2015, 506-507, 323-329. [CrossRef] 
143. Meesters, J.A.J.; Quik, J.T.K.; Koelmans, A.A.; Hendriks, A.J.; Van De Meent, D. Multimedia environmental fate and speciation of engineered nanoparticles: A probabilistic modeling approach. Environ. Sci. Nano 2016, 3, 715-727. [CrossRef]

144. Liu, H.H.; Cohen, Y. Multimedia environmental distribution of engineered nanomaterials. Environ. Sci. Technol. 2014, 48, 3281-3292. [CrossRef]

145. Garner, K.L.; Suh, S.; Keller, A.A. Assessing the risk of engineered nanomaterials in the environment: Development and application of the nanoFate Model. Environ. Sci. Technol. 2017, 51, 5541-5551. [CrossRef] [PubMed]

146. Sani-Kast, N.; Scheringer, M.; Slomberg, D.; Labille, J.; Praetorius, A.; Ollivier, P.; Hungerbühler, K. Addressing the complexity of water chemistry in environmental fate modeling for engineered nanoparticles. Sci. Total. Environ. 2015, 535, 150-159. [CrossRef] [PubMed]

147. Adam, V.; Caballero-Guzman, A.; Nowack, B. Considering the forms of released engineered nanomaterials in probabilistic material flow analysis. Environ. Pollut. 2018, 243, 17-27. [CrossRef]

148. Dale, A.L.; Casman, E.A.; Lowry, G.V.; Lead, J.R.; Viparelli, E.; Baalousha, M. Modeling nanomaterial environmental fate in aquatic systems. Environ. Sci. Technol. 2015, 49, 2587-2593. [CrossRef]

149. Praetorius, A.; Badetti, E.; Brunelli, A.; Clavier, A.; Gallego-Urrea, J.A.; Gondikas, A.; Hassellöv, M.; Hofmann, T.; Mackevica, A.; Marcomini, A.; et al. Strategies for determining heteroaggregation attachment efficiencies of engineered nanoparticles in aquatic environments. Environ. Sci. Nano 2020, 7, 351-367. [CrossRef]

150. Meesters, J.A.J.; Peijnenburg, W.J.G.M.; Hendriks, A.J.; Van De Meent, D.; Quik, J.T.K.; Hendriks, J. A model sensitivity analysis to determine the most important physicochemical properties driving environmental fate and exposure of engineered nanoparticles. Environ. Sci. Nano 2019, 6, 2049-2060. [CrossRef]

151. Praetorius, A.; Scheringer, M.; Hungerbühler, K. Development of environmental fate models for engineered nanoparticles-A case study of $\mathrm{TiO}_{2}$ nanoparticles in the Rhine River. Environ. Sci. Technol. 2012, 46, 6705-6713. [CrossRef]

152. Markus, A.; Parsons, J.; Roex, E.; De Voogt, P.; Laane, R. Modelling the transport of engineered metallic nanoparticles in the river Rhine. Water Res. 2016, 91, 214-224. [CrossRef] [PubMed]

153. Chen, S.H.; Pollino, C.A. Good practice in Bayesian network modelling. Environ. Model. Softw. 2012, 37, 134-145. [CrossRef]

154. Money, E.S.; Reckhow, K.H.; Wiesner, M.R. The use of Bayesian networks for nanoparticle risk forecasting: Model formulation and baseline evaluation. Sci. Total. Environ. 2012, 426, 436-445. [CrossRef] [PubMed]

155. Marvin, H.J.P.; Bouzembrak, Y.; Janssen, E.M.; Van Der Zande, M.; Murphy, F.; Sheehan, B.; Mullins, M.; Bouwmeester, H. Application of Bayesian networks for hazard ranking of nanomaterials to support human health risk assessment. Nanotoxicology 2017, 11, 123-133. [CrossRef] [PubMed]

156. Bilal, M.; Liu, H.; Liu, R.; Cohen, Y. Bayesian network as a support tool for rapid query of the environmental multimedia distribution of nanomaterials. Nanoscale 2017, 9, 4162-4174. [CrossRef]

157. Sahin, O.; Stewart, R.A.; Faivre, G.; Ware, D.; Tomlinson, R.; Mackey, B. Spatial Bayesian network for predicting sea level rise induced coastal erosion in a small Pacific Island. J. Environ. Manag. 2019, 238, 341-351. [CrossRef]

158. Global Market Research Database: Products by Ingredient/Sun Care/World Euromonitor International; Passport: London, UK, 2014-2019.

159. Schaumann, G.E.; Philippe, A.; Bundschuh, M.; Metreveli, G.; Klitzke, S.; Rakcheev, D.; Grün, A.; Kumahor, S.K.; Kuhn, M.; Baumann, T.; et al. Understanding the fate and biological effects of $\mathrm{Ag}$ - and $\mathrm{TiO}_{2}$-nanoparticles in the environment: The quest for advanced analytics and interdisciplinary concepts. Sci. Total. Environ. 2015, 535, 3-19. [CrossRef] [PubMed] 